和泉山脈南麓域における中央構造線の断層変位地形と断層運動

\author{
岡田篤 正*寒川 旭**
}

\begin{abstract}
和泉山脈南麓域の地形・地質調査を行ない，中央構造線沿いの断層変位地形を検証した。さらに，それら を作りだした主として第四紀以降に㧊ける断層運動の諸性格について考察した。中央構造線にほぼ平行ない し一部で雁行状に配列する活断層系があり，それは少なくとも第四紀後期において右ずれ運動が卓越してい る. また，それは内帯 (北側)の和泉山脈側が概して隆起する垂直変位成分(右ずれ成分の約 $1 / 10$ )を有してい る.とくに, 根来断層と五条谷断層が延長距離の長い活断層であるが, 前者は各種の段丘面を切断し, 後者 は山麓南斜面を縦断して大小の右ずれ変位河谷を形成している.

根来断層の右ずれ変位速度は，断層の変位基準である段丘面や段丘崖・河谷や尾根筋の食い違い量とそれ らの形成年代の想定から, $0.9 \sim 3.1 \mathrm{~m} / 10^{3}$ 年, 北側の相対的隆起速度は0.11 0. $40 \mathrm{~m} / 10^{3}$ 年と推算された. 根来断層と五条谷断層について，活断層より上流の河谷長と河谷の屈曲量との関係式を求めると，両者の間 には正の相関がある.これは右ずれの断層変位が累進的に継続していること,さらにA 級の活断層の範疇に 入ることを示唆するが，四国の中央構造線で求められた值より小さい.このことは中央構造線活断層系の東 端部であり, 東方に変位量が減少していくこと, 同時に内帯側の他の多くの活断層にひずみが分散している ことなどによるものであろう.

いわゆる菖蒲谷時階の変動として知られてきた北からの逆断層は，第四紀前期における活動であり，これ は紀ノ川断層角盆地の発生をうながしたが，第四紀後期にはほとんど変位を停止している.この断層の北側 にほぼ並走して高角度の活断層系があり，右ずれの卓越した運動が第四紀後期の少なくとも50万年前以降に 認められる.このように，断層の位置と変位様式に大きな変化が第四紀中頃に生じたことが判明した。
\end{abstract}

\section{I はじめに}

中央構造線は西南日本を内帯と外帯に 2 分して繸 走する重要な地質境界線であり，中生代後期以降に も数回に及ぶ多様な断層活動を経てきたとされてい る.このように地質学的に複雑な活動史をもつ中央 構造線ではあるが，第四紀後期にはほぼ一様に右ず れ成分の卓越する断層運動を行なっており, とくに 四国から紀伊半島中央部にかけての地域で明瞭な断 層変位地形が連続的に認められる.

今回, 調查地域とした和泉山脈南麓域は, 四国に おける中央構造線の菓方延長部であり，その活断層 系の東端部に相当している. また, 近畿三角帯 (Huzita, 1962) の底辺西半分をも占めており, 地形 単元が相対的に小さく南北性の断層が卓越する内帯 と, 地形単元が大きく紀伊山地が曲隆している外帯 との地形構造上の大きな境界になっている. このた めに, 当地域は近畿三角帯内における他の活断層系

* 愛知県立大学 ** 東北大学・院
との関係や広域の地壳運動様式を把握する上でも重 要な位置を占めていると考えられる.

上述の特徴をもつ調查地域において，四国で解明 された中央構造線の断層活動の様式や運動速度（岡 田, 1968, 1970, 1971, 1973 a, b, 1977) などとの関 連についての検討が必要であると思われる。これは 近畿地域のネオテクトニクスや地形発達を考察する 上で重要な意味があるばかりでなく，西南日本の地 殼運動様式を解明する上でも必須の事柄である.

著者らは，紀伊半島西部の中央構造線に沿う地域 において，主として断層変位地形の性格と断層運動 速度を明らかにする目的で調査を進めてきたそその 一部については，すでに予察的な報告を行なった (岡田・寒川, 1976 ; 寒川・岡田，1977). 本稿では, それらをも含めて和泉山脈南縁全域についての調査 結果を述べ，考察を試みる.

調査に当たっては，国土地理院撮影の約 1 万分の $1 ， 2$ 万分の 1,4 万分の 1 などの各種空中写真や, 5 千分の 1 国土基本図，さらに，和歌山県および各 
市町役場発行の 2 千 5 百 3 千分の 1 地形図を用い た. 断層変位量については，巻尺・標尺・ハンドレ ベルなどを用いて測量を行なった，横ずれ変位量の 多くは上述の大縮尺地形図と空中写真から算定した が，変位量の小さい部分は現地で測量した.

\section{II 地形概説}

\section{1. 和泉山脈}

和泉山脈は大阪平野と紀八川河谷を分断しほぼ 東西方向に延びる幅約 $10 \mathrm{~km}$ ，長さ約 $60 \mathrm{~km}$ の地塁 状山地である. この東方は南北方向に走る金剛山地 に移行する.これらの平面形は逆L字ないしブーメ ラン型をなし，特異な形状を呈する(第1図)。また， この山脈は大局的にみれば西方へ緩やかに高度を減
少するが，粉河町北方付近で標高が相当異なる. す なわち，以東では 800 900 $\mathrm{m}$ に及ぶのに対し，以 西では 200 500 m である. 後者ではとくに山頂高 度がそろい，定高性がよく認められる。

和泉山脈を開析する河谷のうち，比較的規模の大 きいものの多くは山脈の主な高所を越えた南側より 発して北流し，大阪平野へ流入する，すなわち，和 泉山脈の分水界は著しく南偏する場所が多く, 谷中 分水界もかなり認められる。 これらは山地の形成過 程を考察する上で重要な意味がある。

2. 段丘面群

粉河町以西では，和泉山脈はほとんどの地域で直 線状に連なる断層崖を境にして段丘面群と接してい る.しかし，粉河町以東では，主な活断層は和泉山

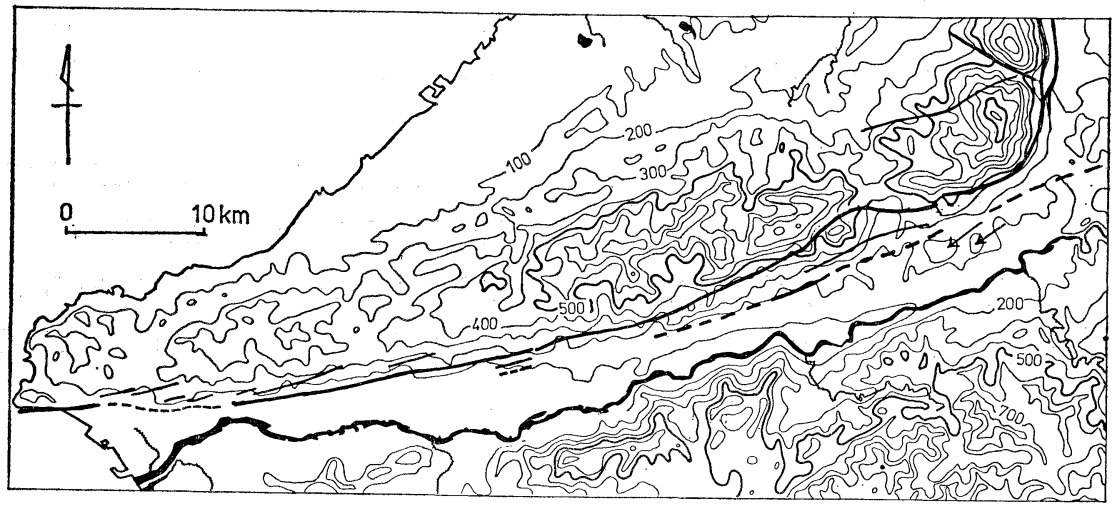

第 1 図-A 調査地域打よび周辺地域の地形概要 5 万分の 1 地形図の谷幅 $500 \mathrm{~m}$ 以内の谷を埋めた埋積接峰面図.

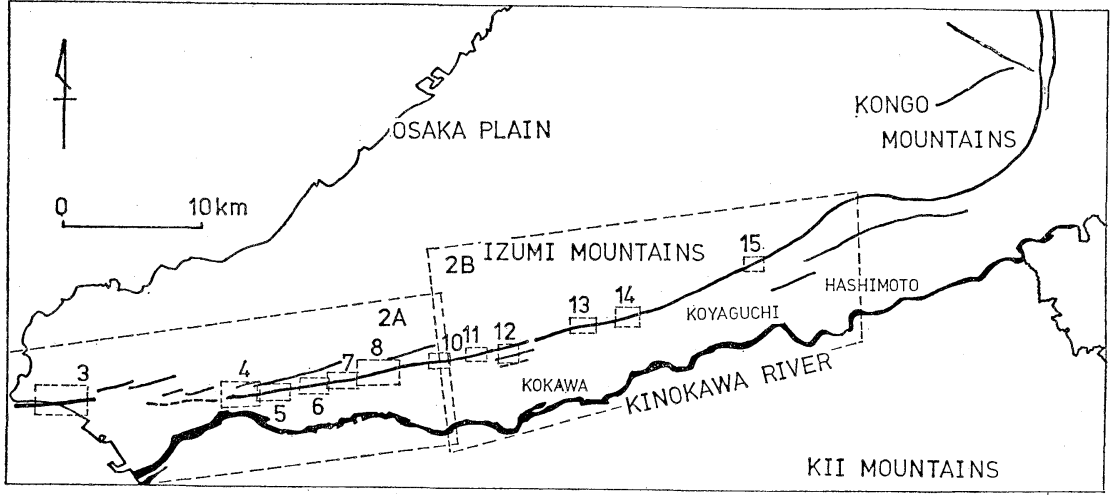

第 1 図-B 調査地域の索引図 数字は図の番号. 
脈と丘陵の境界部，または和泉山脈内の南よりの地 域を走っている(岡田，1973；寒川，1977)。そして, 段丘面群は主要活断層の南に分布する丘陵の南縁か ら広く発達している(寒川，1977)，これらの地域で は，最高位にある五条面を除いて，地形面のほとん どが和泉山脈より南流する支流の形成する(開析) 扇 状地の形態をもっている: とくに，粉河町以西では 古い扇状地面を被覆して，より新しい扇状地性段丘 面群が広く分布している。また粉河町以東では，古 期の段丘面を開析する河谷の中に，より新しい段丘
面が形成されている：このように粉河町付近を境に して，主な活断層の位置も段丘面の発達状態もかな り異なっている.

高野口町以東の段丘面については，寒川(1977)が 上位より五条面・山田面・恋野面・山蔭面・野原 面・二見面・今井面と区分している. この区分は紀 ノ川河谷を通じての適用がほぼ可能であるので，本 稿でもこれらに対応させながら段丘面の分類・対比 を行なった（第 2 図-B）。ただし，粉河町を境にし て地形発達の状態も異なるから, 粉河町以西では,

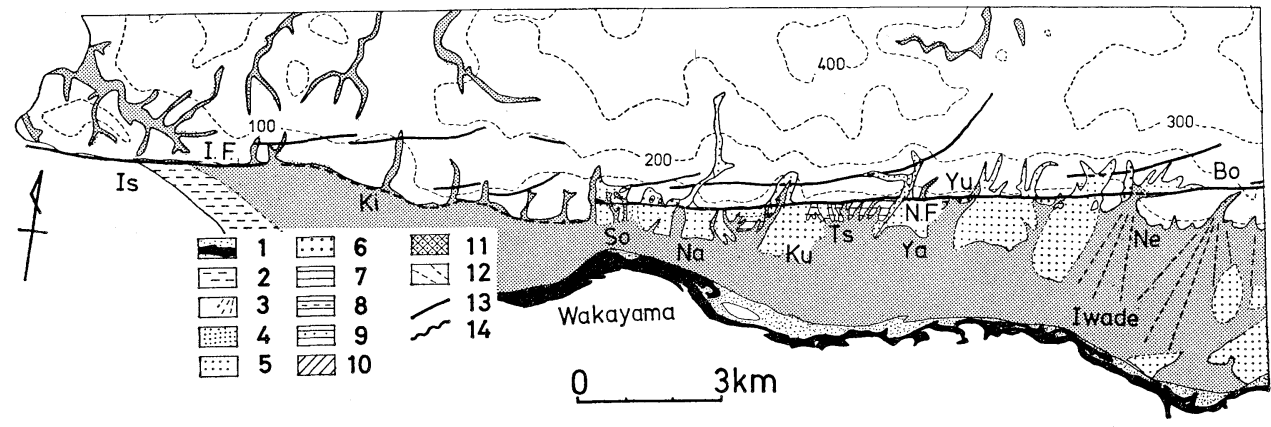

第 2 図-A

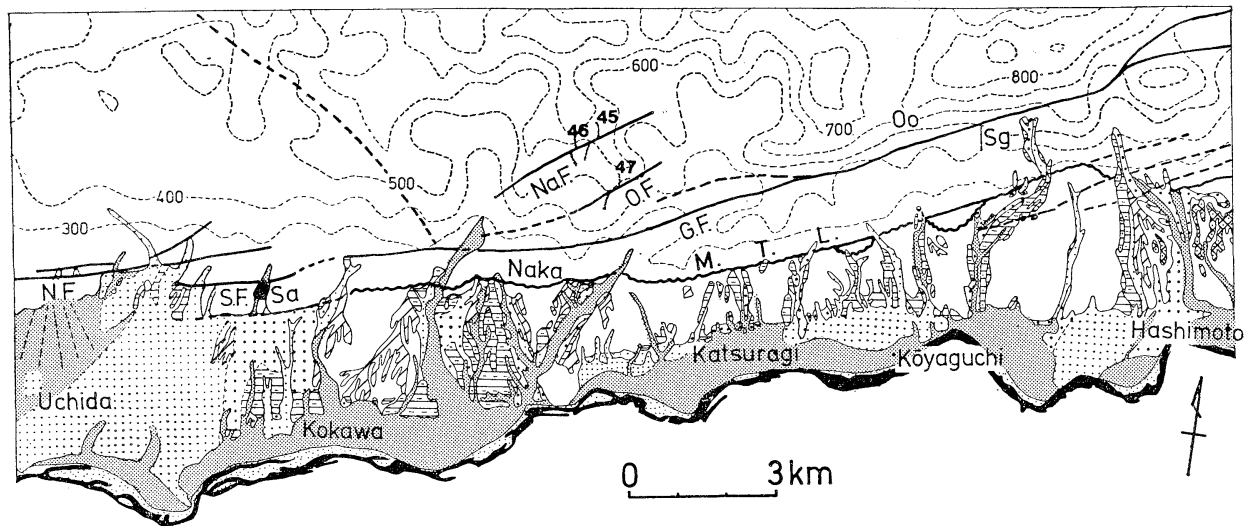

第 2 図-B

第 2 図調查地域の活断層系と段丘面の分布

1. 現河床 2. 砂丘 3. 沖積面(沖積世の扇状地面を含む) $4 . \mathrm{tl}_{3}$ 面 (今井面) $5 . \mathrm{tl}_{2}$ 面 (二見面) $6 . \mathrm{tl}_{1}$ 面 (野原面) 7. $\mathrm{tm}$ 面 8. 山䔖面 9. 恋野面 10. th 面 11. 五条面 12. 丘陵 山地 13. 第四紀後 期に活動した活断層 14. 狭義の中央構造線.

Is : 磯ノ浦 $\mathrm{Ki}$ : 貴志 $\mathrm{So}$ : 園部 $\mathrm{Na}$ : 直川 $\mathrm{Ku}$ : 黒岩 $\mathrm{Ts}$ ：橘谷 $\mathrm{Ya}$ : 山口 $\mathrm{Yu}$ ：湯屋谷 $\mathrm{Ne}$ ：根来 $\mathrm{Bo}$ : 菩提峠 $\mathrm{Bi}:$ 批把谷 $\mathrm{Sa}$ : 桜池 $\mathrm{Oo}:$ 大畑.

Wakayama : 和歌山市 Iwade : 岩出町 Uchida : 打田町 Kokawa : 粉河町 Naka : 那賀町 Katsuragi：かつらぎ町 Kōyaguchi : 高野口町 Hashimoto：橋本市 I. F. : 磯ノ浦断層 N.F.: 根来断層 S. F. : 桜池断層 Na.F. : 中尾断層 O.F. : 大松断層 G. F. : 五条谷断層 M. T. L. : 狭義の中央構造線. 等高線は谷幅 $500 \mathrm{~m}$ 以下を埋積. 
上位より, $\mathrm{th}$ 面・ $\mathrm{tm}$ 面・ $\mathrm{tl}_{1}$ 面・ $\mathrm{tl}_{2}$ 面・ $\mathrm{tl}_{3}$ 面と区 分し, さらに粉河町以東の段丘面と対比する方法を とった(第 2 図-A，第1表).

\section{III 地質概説}

\section{1. 基盤岩類}

和泉山脈の大部分は最上部白亜系の和泉層群によ って構成されているが，大阪平野に接する北縁部や， 金剛山地に接する五条市北方では泉南酸性岩類（中 部白亜系）が分布している. また，紀ノ川河谷内に 孤立する基盤岩の丘陵や，河谷以南の外帯側では三 波川結晶片岩類よりなる. 内帯と外帯の地質境界線 （当域では和泉層群と三波川結晶片岩類との接触部） としての狭義の中央構造線は, 紀ノ川河谷の北縁部 を通るが，ほとんどの場所で鮮新世後期以降の唯積 物に被覆され，その詳しい位置が判らないことが多 い.

\section{2. 第四系}

紀ノ川河谷には，鮮新一更新世の湖沼的環境下で 堆積した菖蒲谷層と，それを覆う中期〜後期更新統 の段丘堆積物が分布している.これらについてはす でに記載している(寒川，1977)ので，詳述をさける.

\section{IV 中央構造線の第四紀における断層}

\section{運動の概要とその研究史}

辻村(1924)は，主として地形図判読から，紀淡海 峡をへだてて四国の吉野川河谷と相対し，著しい縦 谷を形成する紀ノ川河谷を幅の狭い断層角盆地と認 定した.また，辻村(1932)は紀ノ川河谷に沿う断層 に対して紀伊断層群と称し，その中での地形配列に 注目して, 和泉山脈の南側斜面を中部で葛城山断層 崖, 東部で紀伊見峠断層崖と命名した．河田(1939) は紀ノ川河谷の北縁に沿う中央構造線の地質調査を 行ない，河谷内に分布する小磁・砂・粘土よりなる 堆積物を菖蒲谷層と名付けるとともに, 菖蒲谷層堆 積以降にも断層運動が存在したことを指摘した. 小
林(1941，1951)はこれに葛蒲谷時階の名称を与えた が，以後，一般にこれが中央構造線の最新の活動で あると考えられてきた.

しかし, Kaneko(1966)によって, 主として空中 写真判読結果から, 中央構造線の新期活動は右ずれ 成分が卓越すると指摘された，これに引き続き四国 の吉野川南岸で右ずれ断層の存在が認められた（寺 戸，1967）。さらに，四国の中央構造線全域におい て，岡田(1968, 1970, 1971, 1972, 1973 a, b, 1977) が野外調査を行ない，各種の地形・地質学的証拠か ら，第四紀後期における右ずれ運動を具体的に検 証した．最近では，紀伊半島中西部においても， 断層の位置・変位様式が具体的に解明されてきた (藤田，1968，1974；藤田・奥田，1973；松田， 1973 ; 岡田, $1973 \mathrm{~b}$; 岡田・寒川, 1976 ; 寒川 • 岡 田, 1977)。

菖蒲谷層を切る断層活動についても多くの研究が なされてきた（河田，1939；小林，1941，1951；鈴 鹿，1958；志井田，1953，1954）が，その活動時期 は新期堆積物や地形との対応から再検討されるよう になってきた（梅田，1973； Miyata et al., 1974； 市川ほか, $1976 \mathrm{a}, \mathrm{b}$; 寒川・岡田, 1977 ; 寒川ほ か, 1977 ; 近畿西部 MTL グループ, 1977). これ らの多くは逆断層形式の運動であり, 地質的表現 の見事さとは逆に，変位地形は不明瞭なので，右横 ずれ成分の卓越する以前の活動であると考えられ てきた（藤田，1968；岡田，1973b；寒川，1977； 寒川・岡田, 1977 ; 寒川ほか, 1977). しかし, 変 位地形の詳しい検討から，第四紀後期の断層変位様 式や速度・発生時期に関して充分な研究がなされて いないので，次に，このような問題について基礎事 実を述べる.

\section{V 中央構造線の第四紀後期における} 断層運動についての地域的な記載

和泉山脈南麓においては，第四紀後期に活動的な 
断層の中で，とりわけ根来断層（市川ほか，1976 a ; 岡田・寒川, 1976 ; 寒川・岡田, 1977）と五条谷断 層（近畿西部 MTL グループ，1977）が，変位地形 の鮮明さや断層の長さの点で卓越している. 根来断 層は，粉河町以西の地域で山地と段丘面群を境して おり，五条谷断層は，粉河町以東で山地と丘陵の境 界部を走り, さらに東北東に延長して山地を通過し ている. 両者は粉河町北方で雁行配列をしている (第 2 図-B). これらは共に狭義の中央構造線の北 側を並走し, 基盤岩の和泉層群中を通過している. 根来断層は狭義の中央構造線の北側に沿う幅数 100 m の大破砕帯（市川・宮田，1973；市川ほか，1976 a) の北縁部付近に位置している. 五条谷断層は北 東に行くにつれて狭義の中央構造線から遠ざかり， 2 3 km 北方を通過するようになる. この 2 つの断 層およびその他の主な活断層を中心に，西方から東 方へと地域別に述べる.

1. 根来断層より西の地域

（1）和歌山市北西部，磯ノ浦周辺（第 3 困）
この地域は和泉山脈の南西端に当たり，山脈と海 域(紀淡海峡)・沖積平野(和歌山平野)がほぼ直線的 な急崖で接している. 山脈は和泉層群によって構成 され，狭義の中央構造線は紀淡海陕および沖積平野 の北縁を通過していると推測される。

この急崖に沿って明瞭な風陌(谷中分水界)地形が 大小合わせて13か所において認められる.さらに， 第 3 図の西方約 $1 \mathrm{~km}$ の紀淡海峡に面する田倉崎付 近にもみられる.これらはほとんどが北流水系の最 上流部(高度 7〜 47 m) にあるので，旧谷底はかつて 中央構造線以南に達していたと考えられる. そして, 山麓線は直線的によく連なり，三角末端面の地形も 連続することから，この急崖下を活断層（磯ノ浦断 層 : 新称）が通過すると推定される. この断層の新 しい活動(北側の相対的上昇)によって旧水系が切断 され，多数の風隙地形が作られたと考元られる.

（2）和歌山市北部，貴志～園部（第 2 図-A） この地域では，和泉層群よりなる高度 $100 \sim 200 \mathrm{~m}$ の丘陵地・山地が広く分布し，さらにその南に沖積

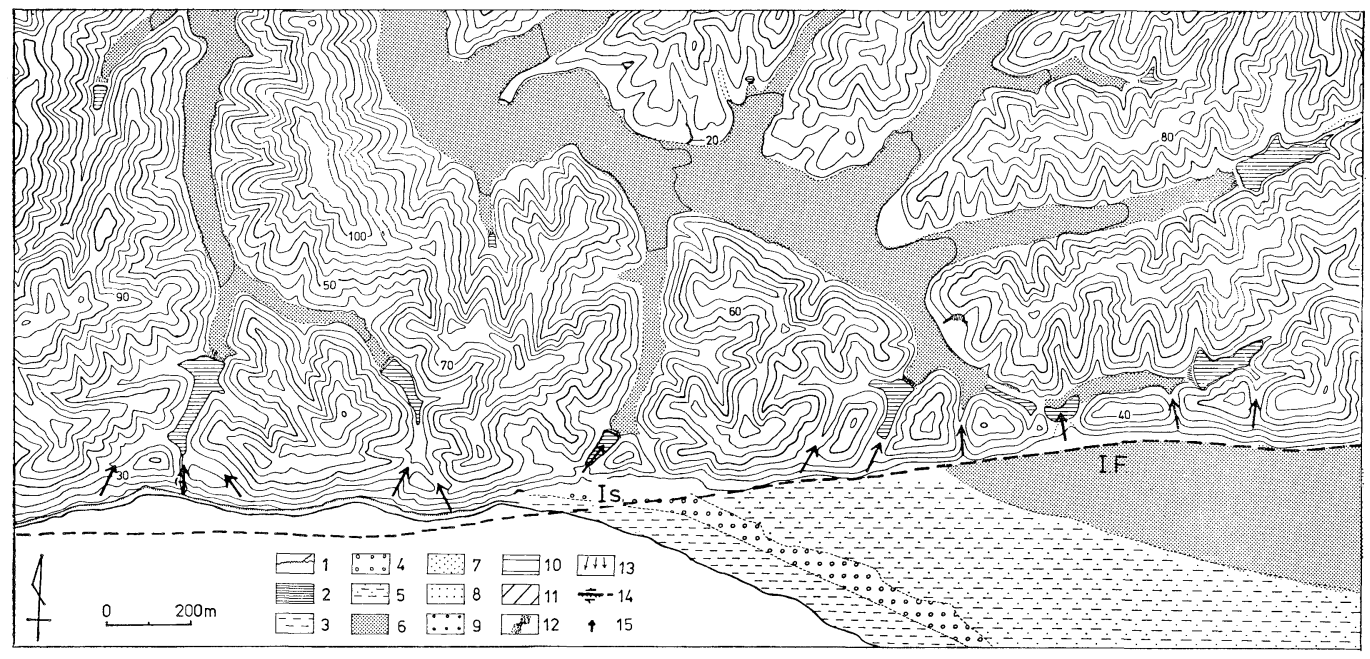

第 3 図磯ノ浦周辺の地形

Is : 磯ノ浦 I. F. : 磯ノ浦断層.

1. 現河床 2. ため池 3. 砂浜 4. 浜堤 5 . 砂丘 6. 沖積面 7. $\mathrm{tl}_{3}$ 面 8. $\mathrm{tl}_{2}$ 面 $9 . \mathrm{tl}_{1}$ 面 $10 . \mathrm{tm}$ 面 11. th 面 12. 変位河谷 13. 面の傾斜方向 14. 第四紀後期に活動した活断層 15. 風隙地形. 数字は河谷番号を, $a-a^{\prime} \sim h-h^{\prime}$ は第 9 図の断面の位置を示す.

第 $3 \sim 11$ 図の等高線は各市町役場発行の $1 / 2500$ 地形図に基づく.また第 $3 \sim 15$ 図の凡例も共通である. 
面が分布している. 山地と沖積面との境界はかなり 湾曲しているが，比較的明瞭な高度差がある。山 地・丘陵地を構成する和泉層群は南縁付近でかなり 広域的に(幅 $800 \mathrm{~m}$ 以上で) 破砕されているが, 明瞭 な断層変位地形は認められない，つまり，東西方向 のリニアメントが分散的にみられるのみで，卓越し た 1 本の活断層としては地形・地質上表現されてい ないようである。

2. 根来断層沿いの地域

根来断層は延長 $20 \mathrm{~km}$ に及ふ断層で，段丘面群 を連続的に切断し，段丘崖・丘陵を開析する河谷・ 丘陵の尾根筋などを右ずれ方向に屈曲させている (岡田・寒川，1976；寒川・岡田，1977)。西半部の $10 \mathrm{~km}$ の区間に拈ける垂直変位は南落ちであるが, 東半部になると北落ちのところもみられる.この断 層の地形的表現は全体として実に鮮明であり，地 質的にもその存在が確認されている（市川ほか， $1976 \mathrm{a}$; 岡田・寒川, 1976 ; 寒川 - 岡田, 1977)。

（1）和歌山市北東部，園部～直川（第 4 図） 根来断層は断層の北側まで分布する数段の開析扇 状地面を切断して，園部から $\mathrm{N} 80^{\circ} \mathrm{E}$ 方向に直線的 に延び, 低断層崖や撓曲崖を各地で伴っている. 扇状 地面を開析する河谷の大部分は，根来断層と交差す
る所で右ずれ方向に食い違いを示している.

河谷 1 （以下，明瞭な変位河谷に西方から一連番 号をつける）は，その両側に分布する $\mathrm{tl}_{3}$ 面の段丘 崖を右ずれ方向に食い違わせている，その水平変位 量は西岸で $13.5 \mathrm{~m}$ ，東岸で $10.0 \mathrm{~m}$ と測定された. この場合も含めて，西岸の段丘崖の水平変位量がや や大であることが多い：これは，東岸の段丘崖が変 位後に下流測を塞ぐようになるので，より多く浸食 されることを示唆している，そこで，このような場 合，水平変位量の指標としては西岸の值がより妥当 と思われる。

第 2 表に断層変位量を記入したが，水平変位量に ついては，変位地形の保存状態を吟味して，信頼度 の高いものより $\mathrm{A} ， \mathrm{~B} ， \mathrm{C}$ 格付けをした，Aは水 平変位量がかなりよく測定できたもの，Bはその精 度がよくないが概略值を測定できたもの，Cは変位 量の測定が不可能であるが変位の方向はわかるもの である．垂直変位量は現地で直接測定するか，また は地形断面(第 9 図)より算定した.

河谷 1 の東西延長上では，段丘面が垂直方向にも 切断され，南落ちの変位を示している（第 9 図 C$\mathrm{C}^{\prime}$ ). しかし，やや西方になると，根来断層そのも のの垂直変位量はなくなるか，またはむしろ北落

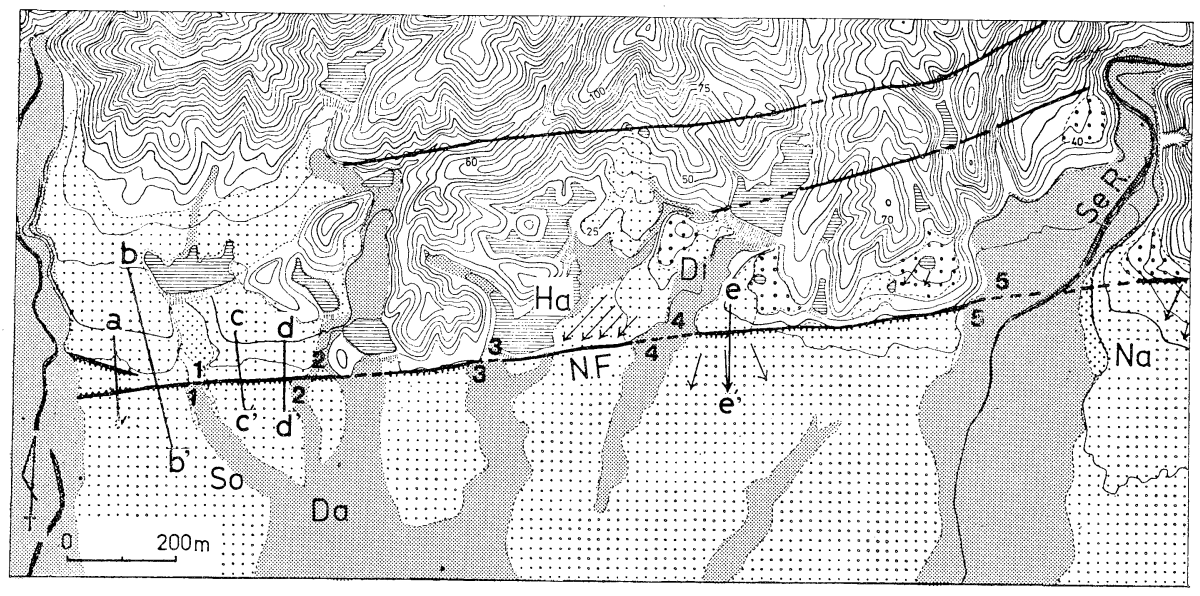

第 4 図園部〜直川の地形

So: 園部 $\mathrm{Da}$ : 伊達神社 $\mathrm{Ha}$ : 蓮池 $\mathrm{Di}$ : 大同寺 $\mathrm{Na}$ : 直川 $\mathrm{SeR}$ : 千手川 N.F.：根来断層. 
ちとなる. そして, 断層の北側の幅 $100 \mathrm{~m}$ 以内の 部分が撓曲し(第 9 図 $b-b^{\prime}$ ), 部分的に溝状凹地 (fault trench) を形成している(第9図 $\left.a-a^{\prime}\right)$ 。 の西方の丘陵には変位地形が認められず, 根来断層 はこの付近から消滅していくものと思われる. 伊達 神社北方の河谷 2 でも, 扇状地面の垂直方向の切断 (第 9 図 d-d') と河谷の右ずれ方向への屈曲が認 められる. また, 河谷 3 の西岸にも右ずれを示す地 形が残っている. 大同寺のある河谷 4 の東岸には明 瞭な低断層崖がみられる(第 9 図 $\mathrm{e}-\mathrm{e}^{\prime}$ ) が，西岸は 撓曲崖状の緩斜面となっている.ここでは, 両岸の 段丘崖が右ずれを示す方向に食い違っており, 变位 量も両岸でほぼ等しい值となっている. 河谷 5 (千 手川)の西岸にも鮮明な断層崖がみられ，段丘崖も 右ずれ方向に屈曲している.

（2）和歌山市北東部，直川 黒岩（第 5 図）

当域では $\mathrm{tl}_{2}$ 面が扇状地面として広く分布するが, $\mathrm{tm}$ 面は野村〜今滝付近でわずかにみられる. 根来断 層は山地と段丘面のほぼ境界を通過している. 野村 北方の $\mathrm{tl}_{2}$ 面を開析する河谷 $6 \cdot 7 \cdot 8$ は根来断層に よってほぼ等しい量だけ右ずれ方向に変位している. 河谷 9 の東岸 (河谷 10 の西岸) の扇状地面 ( $\mathrm{tm}, \mathrm{tl}_{2}$ 面）は垂直方向に切断されており（第 9 図 $\left.f-f^{\prime}\right)$,
河谷10の東岸でも撓曲崖状の斜面がみられる（第 9 図 $\left.\mathrm{g}-\mathrm{g}^{\prime}\right)$.

（3）和歌山市東北東部，橘谷 山口（第 6 図） 当域では合流扇状地面として $\mathrm{tm}$ 面が広く分布し これを開析する谷中には $\mathrm{tl}_{2}$ 面が認められる.この 付近の根来断層は, 市川・宮田(1973), 岡田・寒川 (1976), 寒川・岡田(1977)によって地質学的に確認 されている. 山口の七瀬川西岸沿いの露頭 (Loc. 1) でかつて連続的に断層露頭が確認された（寒川・岡 田, 1977). そして, 基盤岩と $\mathrm{tm}$ 面の堆積物が見掛 け上逆断層 (走向 : $\mathrm{N} 85^{\circ} \mathrm{E} \sim \mathrm{N} 85^{\circ} \mathrm{W}$, 傾斜 : $39^{\circ} \sim$ $\left.49^{\circ} \mathrm{N}\right)$ で接している. また，この断層より約 $100 \mathrm{~m}$ 南側の急斜面に沿って副次的な断層が存在するもの と考えられる (寒川・岡田，1977). tm 面を開析す る多くの河谷の中でも，河谷11〜15で右ずれを示す 系統的屈曲がかなりはっきり残されており，屈曲量 も少し大きな値(第2表)を示している.

（4）和歌山市東部，山口～湯屋谷（第 7 図） 当山麓域には, $\mathrm{tl}_{2}$ 面が七瀬川・雄ノ山川などの形 成した合流扇状地面として広く分布している. 山地 との境界付近では，これらの扇状地面に埋め残され て $\mathrm{tm}$ 面・ $\mathrm{tl}_{1}$ 面がわずかにみられる. 七瀬川東岸や 雄ノ山川西岸では, 根来断層に沿って扇状地面が切

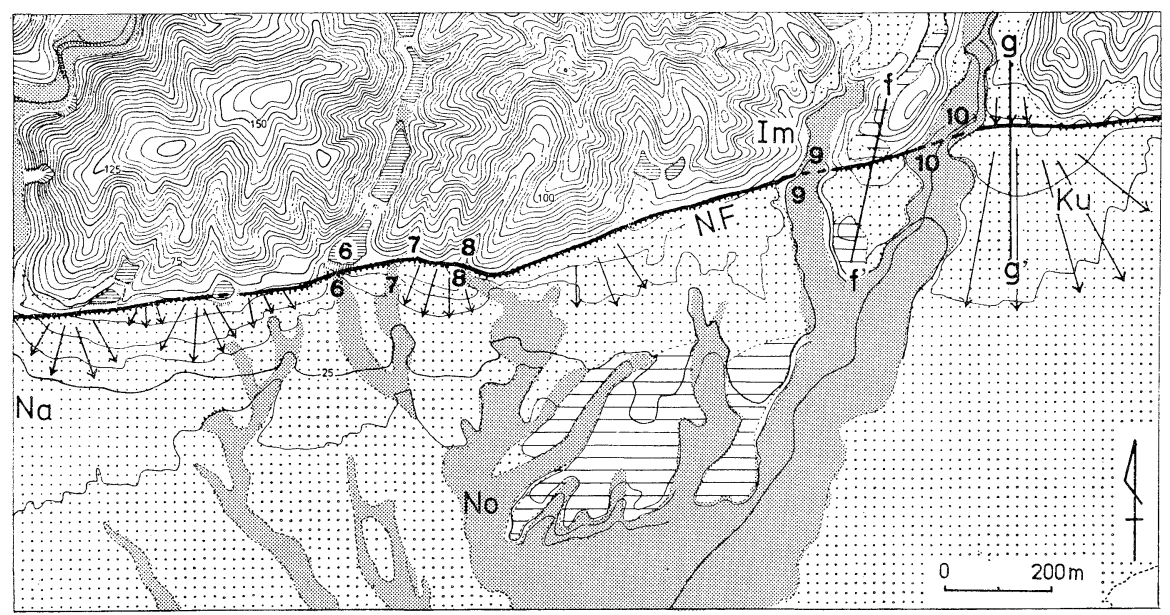

第 5 図直川〜黒岩の地形

$\mathrm{Na}$ : 直川 No：野村 Im：今滝 Ku：黒岩 N. F. : 根来断層. 


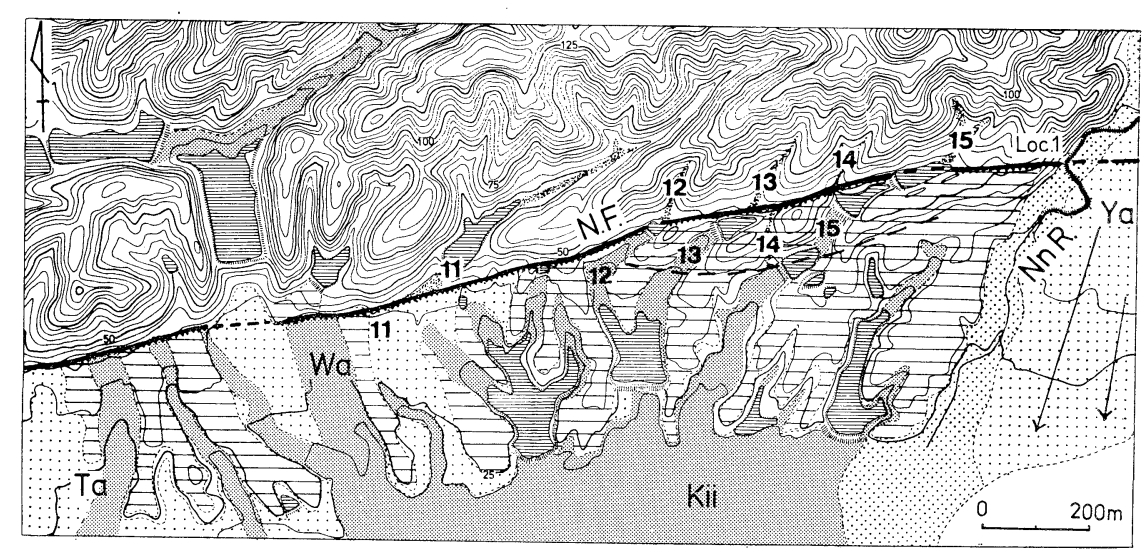

第 6 図橘谷〜山口の地形

$\mathrm{Ta}$ : 橘谷 $\mathrm{Wa}$ : 和歌山医大 $\mathrm{Ya}$ : 山口 Kii : 紀伊 NnR：七瀬川 N. F. : 根来断層.

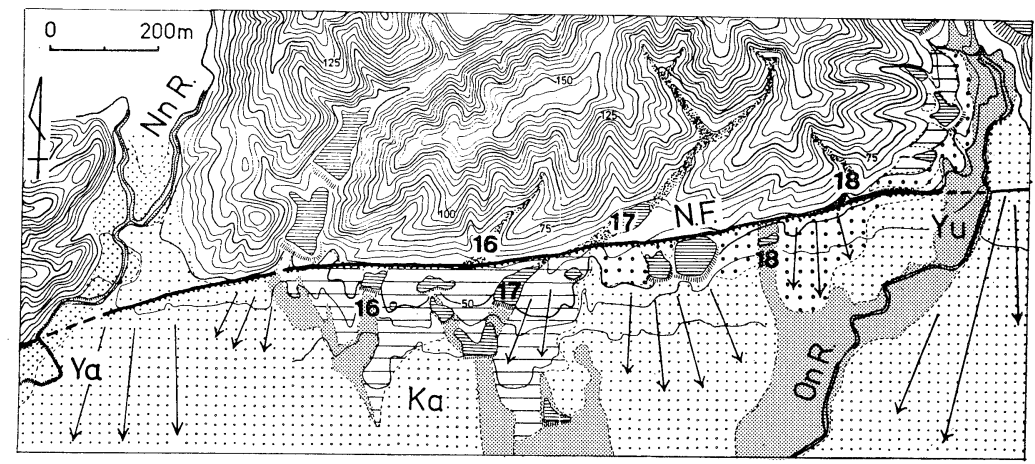

第 7 図山口〜湯屋谷の地形

$\mathrm{Ka}$ : 上黒岩 $\mathrm{Ya}$ : 山口 $\mathrm{Yu}$ : 湯屋谷 NnR : 七瀬川 OnR : 雄ノ山川 N. F. : 根来断層.

断されている. また, $\mathrm{tm}$ 面や $\mathrm{tl}_{1}$ 面を開析する河 谷16〜18は根来断層沿いに右ずれ屈曲がみられる.

(5) 岩出町西部，山 安上 (第 8 図)

この地域の山麓域には雄ノ山川や住吉川の形成に よる $\mathrm{tl}_{2}$ 面が開析扇状地面としてかなり広く分布し ている.この扇状地面の境界付近に埋め残された形 で $\mathrm{tm}$ 面， $\mathrm{tl}_{1}$ 面がみられる. 河谷 19 は段丘崖が出 ロを塞ぐような状態になっており，河谷20は右ずれ 方向に明瞭に屈曲している. また, 河谷19の西側で $\mathrm{tl}_{2}$ 面が根来断層によって切断され，南に低断層崖 を向けている(第9図 h-h').

安上付近には, 根来断層の北側の $\mathrm{tl}_{2}$ 面中に和泉 層群よりなる孤立丘陵があり，この断層の新しい時 代の活動で北側が相対的に上昇していると予想され
る. しかし, $\mathrm{tl}_{2}$ 面の垂直方向の断層変位量は不明 瞭になってくる. そして，この地域以東になると根 来断層の相対的垂直変位成分は逆に南上りの場合が 多くなってくる. 前述の孤立丘陵のすぐ西側で $\mathrm{tl}_{2}$ 面を刻む小河谷が，根来断層に沿って約 $20 \mathrm{~m}$ 右ず れ方向に屈曲している. この河谷はかなり新しく生 ビたものらしい.

（6）岩出町東部，菩提峠付近（第10図）

根来断層の南側に沿って和泉層群よりなる断層分 離丘陵（東西 $4 \mathrm{~km}$, 幅 $0.7 \mathrm{~km}$, 最高点の標高 203.7 m）がある. その丘陵の南縁より扇状地面が広く分 布しているが，この面は沖積面との境界が不明膫で あることや，ほとんど開析を受けておらず，扇状地 の形態がよく保存されていることなどから沖積扇状 


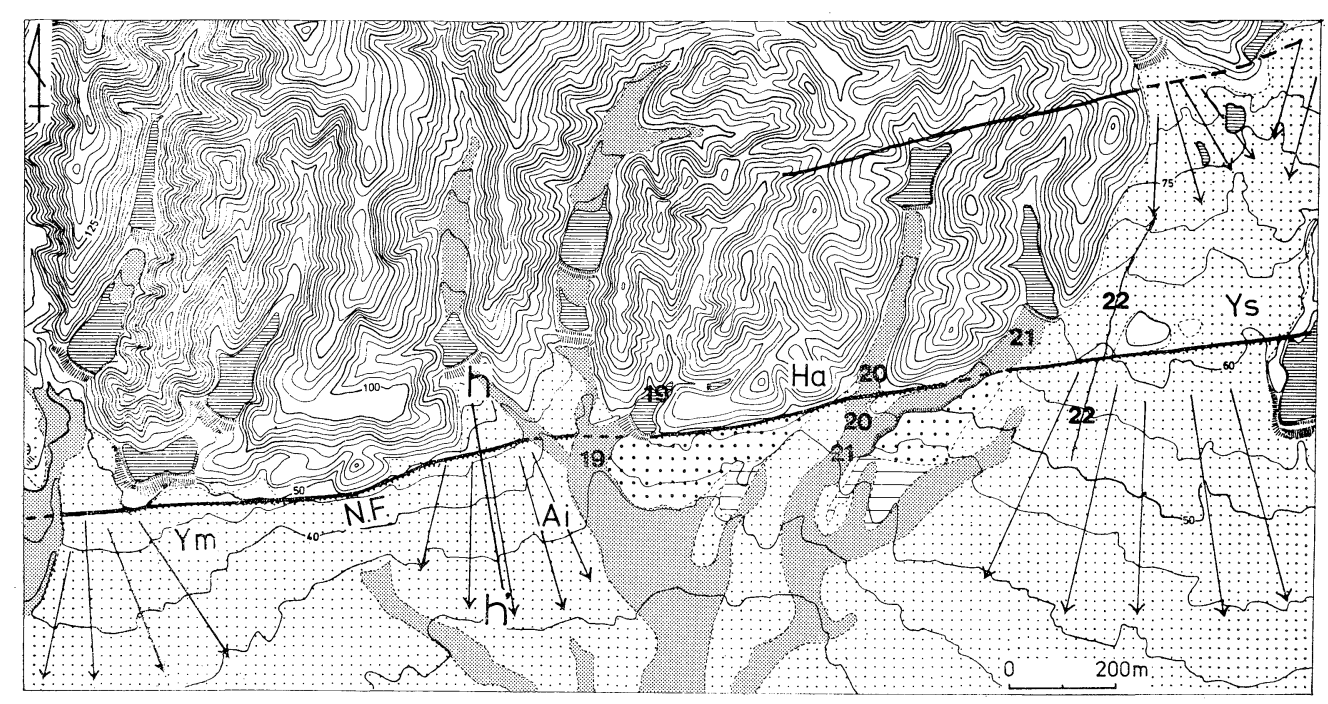

第 8 図山〜安上の地形

$\mathrm{Ym}$ : 山 $\mathrm{Ai}$ : 相谷 $\mathrm{Ha}$ : 原 Ys : 安上 N.F. : 根来断層.
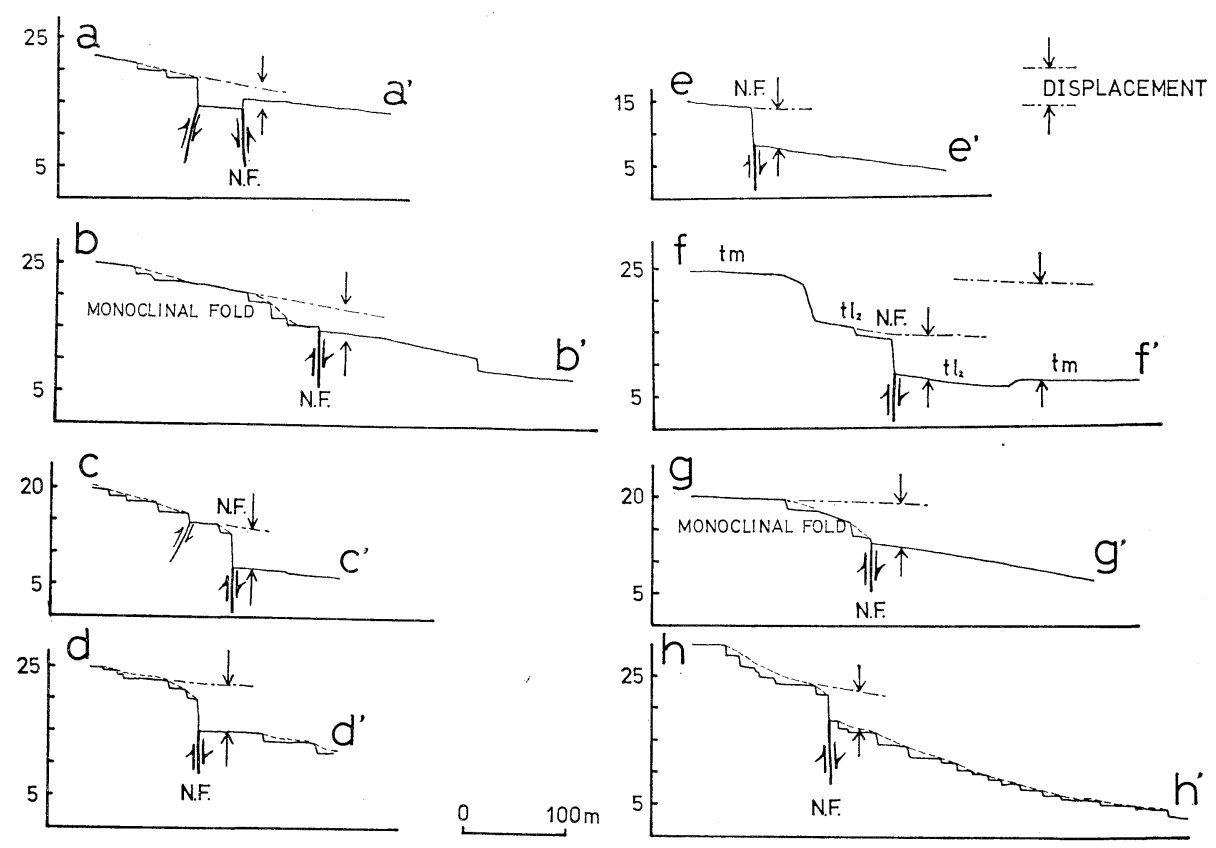

第 9 図根来断層に沿う地形断面図

地表は水田化が進んでいるので，原地表面を推定し，破線で示した。

地面に近いと考えられる (第 2 図-A)．河谷 23 と 30 はかなり規模の大きい河谷であり，1 1.5 kmの大 きな右ずれ屈曲を示している. 河谷 30 内にある小さ
な河谷 $24 \sim 29$ は $50 \mathrm{~m}$ 前後の右ずれを示す屈曲（第 3 表) がよく連続している.

この付近の断層露頭については，すでに市川ほか 


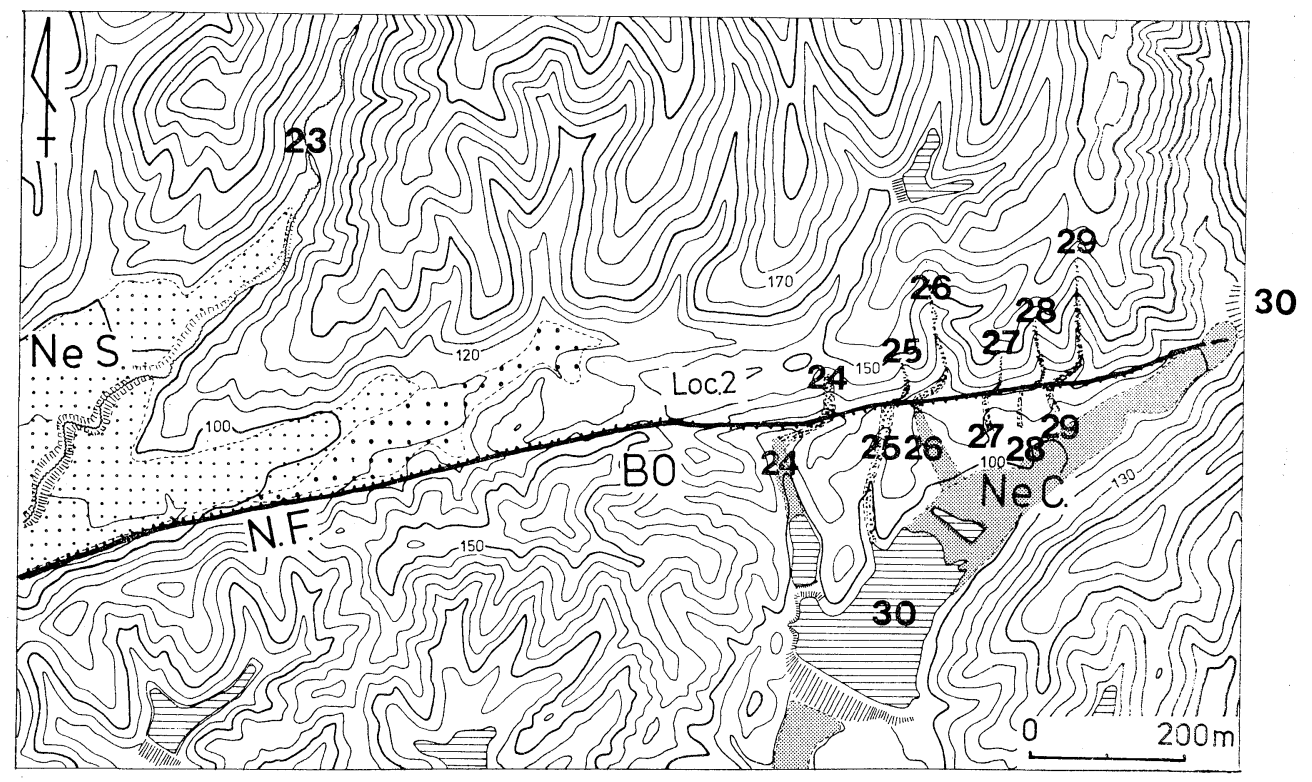

第10図菩提垰付近の地形

$\mathrm{NeS}$ : 根来寺 Bo：菩提峠 $\mathrm{NeC}$ : 根来クレ一射撃場 N. F. : 根来断層.

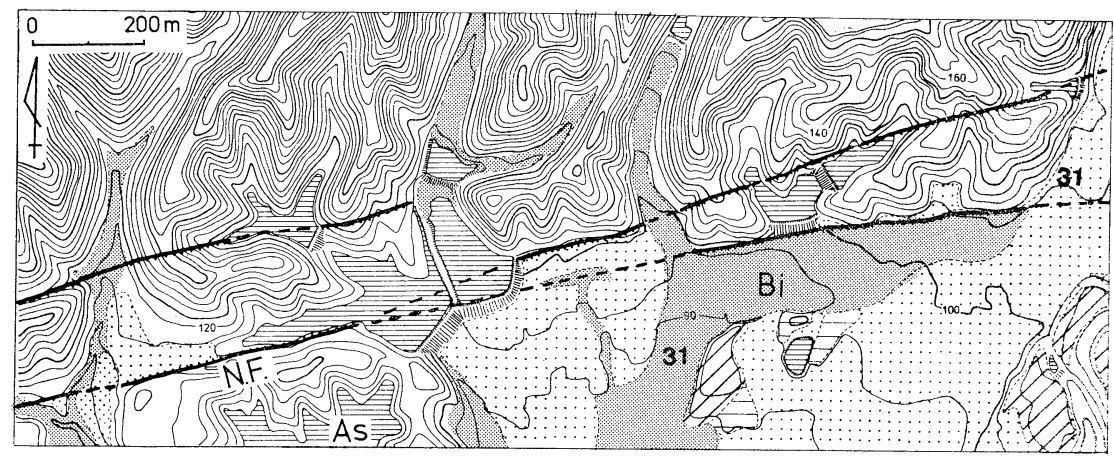

\section{第11図批把谷付近の地形 \\ As：あさ打池 Bi : 批把谷 N.F.: 根来断層.}

(1976 a)，岡田・寒川 (1976) に記載されており，

Loc. 2 でよく観察できる. ここでは, 走向 : $\mathrm{N} 80^{\circ} \mathrm{E}$, 傾斜 : $70^{\circ} \mathrm{S}$ の断層面を境として和泉層群が北側の 菖蒲谷層（外帯由来碟を多く含み，最下部の基底礫 岩に近いと推定される）と逆断層関係で接している. 根来以西で一様に南落ちを示してきた根来断層も, これより東方では場所によって垂直変位の方向が異 なってくる. また，根来の北方では，根来断層の北 側約 $500 \mathrm{~m}$ を並走する，右ずれ成分をもった別の 活断層(延長約 $3 \mathrm{~km}$ )がみられる(第 2 図).
（7）打田町東部，批把谷付近（第11図）

この地域では $\mathrm{tl}_{2}$ 面が山簏に扇状地状の分布形態 をなして広く発達し，局所的に tm・ th 面が残丘状 に保存されている．根来断層はこの地域で隣接する 2 本の断層に分かれている. 河谷 31 は丘陵状の地形 面を開析し，断層の部分で大きく屈曲している．ま た，あさ抢池北西方では $\mathrm{tl}_{2}$ 面相当の段丘面が北落 ち方向に切断されている.

（8）粉河町西部，桜池付近（第12図）

根来断層による変位地形はこの付近まで認められ， 


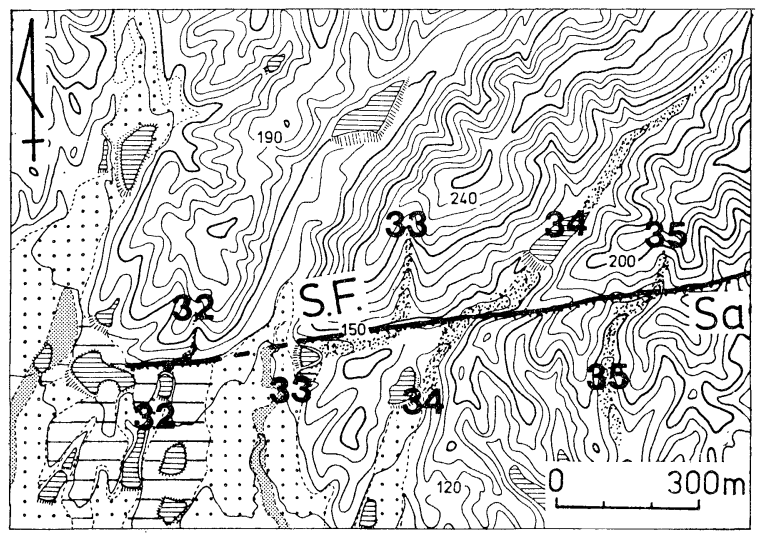

第12図桜池付近の地形

Sa : 桜池 S. F. : 桜池断層.

第 12 14 図の等高線は国土地理院発行の 1/5000 国土基本図に基づく.

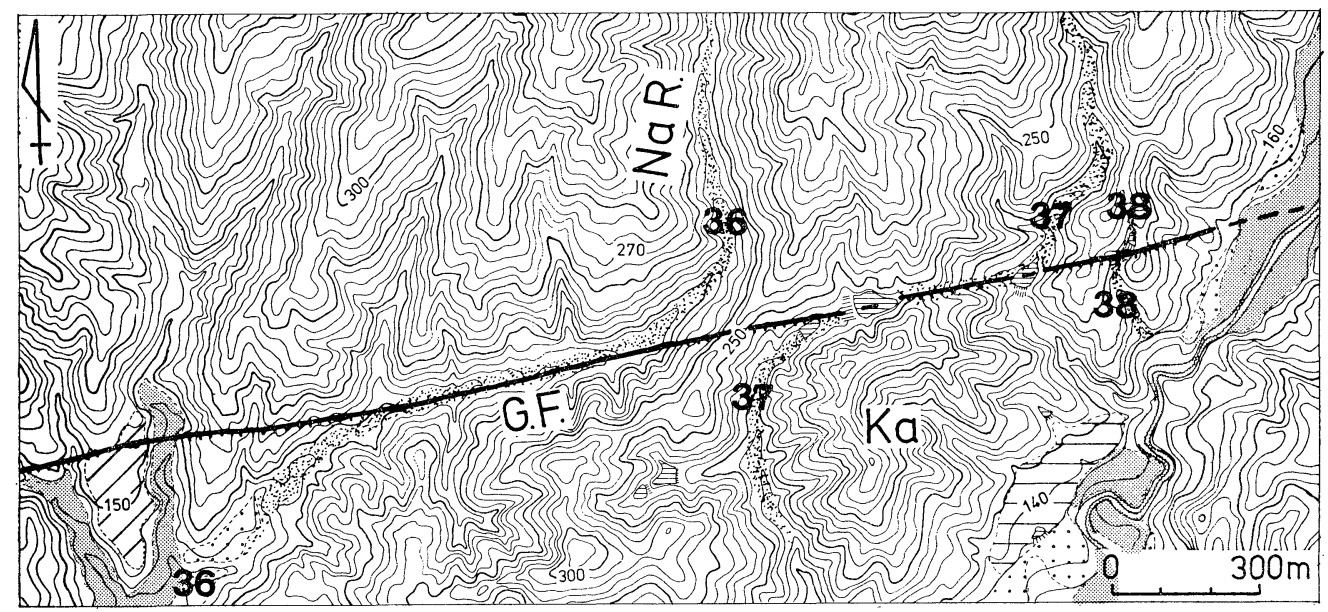

第13図粉河町北方の地形

$\mathrm{Ka}$ ：上丹尘谷 $\mathrm{NaR}$ : 中津川 G. F. : 五条谷断層.

丘陵尾根を横断しているが，ここより東方では変位 地形が不明瞭となる (第 2 図-B). むしろ, 根来断層 より約 $600 \mathrm{~m}$ 南側を並走する別の断層（桜池断層 : 新称) 沿いに，右ずれを示す河谷 $(32 \sim 35)$ の系統的 屈曲と丘陵尾根の高度の不連続が認められる（第12 図). さらに約 $600 \mathrm{~km}$ 南側でも, 丘陵の南縁が東西 方向へ直線的に約 $2.5 \mathrm{~km}$ 以上連なるので, これに 沿って活断層が通過すると推定される(第 2 図-B).

3. 五条谷断層沿いの地域

五条谷断層は近畿西部 MTL グループ(1977)によ
って断層破砕帯が各所でよく確認されている．破砕 帯の幅は数 $\mathrm{m} \sim 100 \mathrm{~m}$ 前後とされ，狭義の中央構造 線に比べると破砕の程度はかなり弱い，しかし，断 層変位地形の鮮明さは五条谷断層の方がはるかにま さっている. この断層について地域別に記述する.

（1）粉河町北方～那賀町北方（第13図，第14図） 山地・丘陵地を開析する中規模の河谷 $(36,37$, 39，44)は，Kaneko(1966)によって指摘されたよう に0.5 1. $4 \mathrm{~km}$ に及ぶ右ずれ屈曲を示している. し かし，小さな河谷 $(38 ， 40 \sim 43)$ では $50 \mathrm{~m}$ 前後の右 


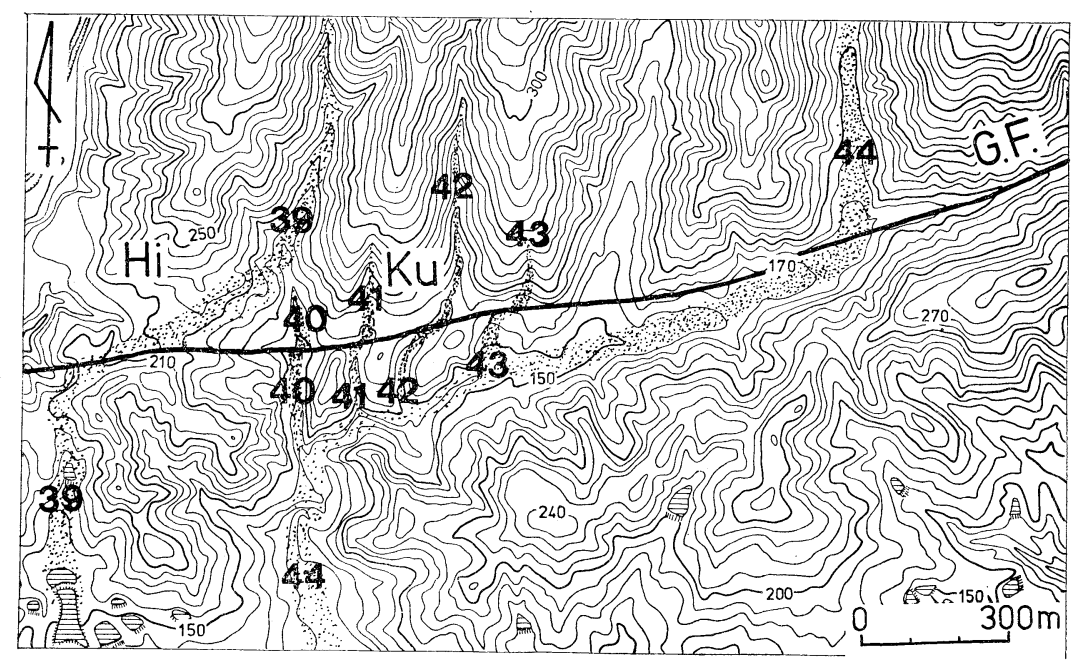

第14図那賀町北方の地形

$\mathrm{Hi}$ : 東川原 $\mathrm{Ku}$ : 葛谷 G. F. : 五条谷断層.

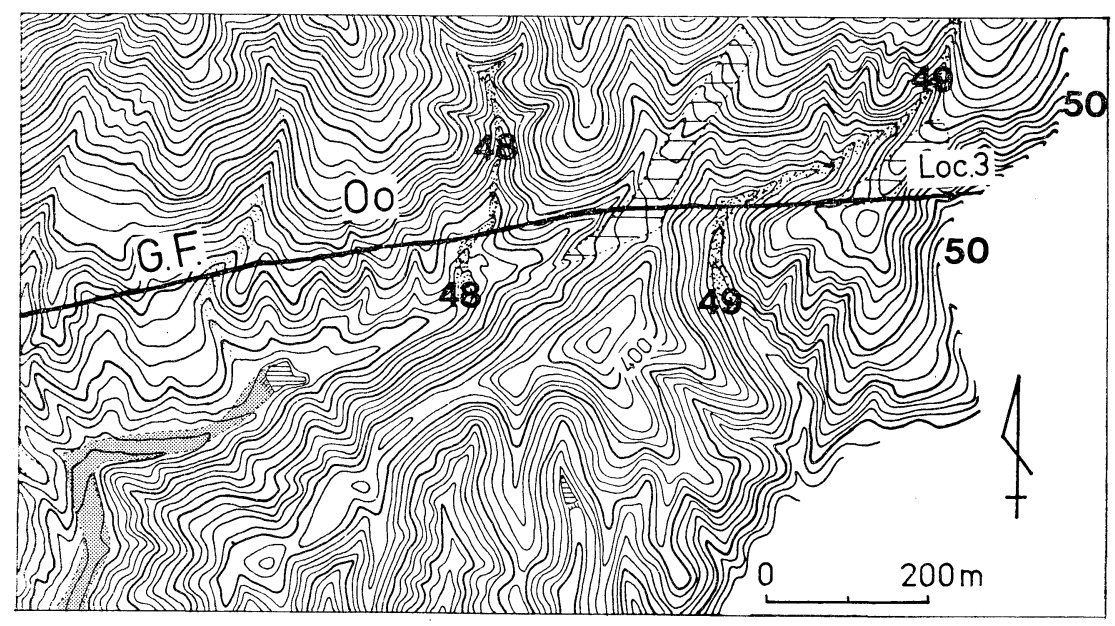

第15図大畑周辺の地形

Oo：大畑 G. F. : 五条谷断層.

等高線はかつらぎ町発行の $1 / 1000$ 地形図に基づく.

ずれ屈曲が認められる. 垂直変位量はあまりはっき

りしないが, 山地や丘陵地の高度不連続から概算し

て，それらの概形形成後に少なくとも $250 \mathrm{~m}$ 以上の

值で南側が相対的に低下していると考えられる.

また，この北側に並走して 2 本の断層（中尾断層， 大松断層：いずれも新称, 第 2 図-Bの中央部) が認 められ，共に山地を開析する河谷 (45〜47) を右ず れ方向に屈曲させている. そして, 尾根の高度不連
続からみて，それぞれ $250 \mathrm{~m}, 200 \mathrm{~m}$ 程度と南側が 落ちているようである.

（2）かつらぎ町北部，大畑周辺(第 2 図，第15図) 上述の地域の東方延長上では, 五条谷断層はほぼ 直線状に山地内を通過しているが，浸食の著しい急 傾斜地であるため, 変位地形はやや不明瞭になる. 山地の尾根高度は約 $400 \mathrm{~m}$ 南側が低く, この断層を 横切って南流する河谷(48～50)は右ずれを示す屈曲 
をしている. かつらぎ町大畑(Loc. 3)では, 崖錐状 の段丘堆積物と和泉層群と断層関係で接する露頭が ある. この断層面はほぼ垂直で, 北側方見掛け上低 下しているが，水平成分の大きい断層ではこのょう な接触関係が生じることもあり，南側低下の全般的 傾向を否定するものではない．

（3）瑳珴谷以東～橋本市北西部（第 2 図-B）

五条谷断層は約 $16 \mathrm{~km}$ にわたってほぼ直線的に 連続するが, 瑳珴谷より $2.5 \mathrm{~km}$ 東の山田川と交差 する付近（第 2 図-Bの東端）より東方では北側へ凸 形を描くように湾曲する。この地域には断層の北側 に和泉山脈中で最も高い岩湧山 $(898 \mathrm{~m})$, 南側にも 三石山 $(739 \mathrm{~m})$ がみられる. 当域は高角度の右ずれ 断層が湾曲する部分であるから，右ずれが進行する と, 進向方行の湾曲部の両側は物質過剩となり, 隆 起したものと考元られる. 上述の, 周辺に比べて異 常に高い山地はそのような成因とみなされる.

4. 狭義の中央構造線沿いの地域(第 2 図-A，B）

（1）粉河町以西（第 2 図-A，B）

この地域では狭義の中央構造線は根来断層の南側 に存在することが推定されている（市川ほか，1976 a). 新旧の扇状地面下に埋積されているので，その 正確な位置については不明である.これに沿って扇 状地面を変位させるような活動はみられない。

（2）粉河町～那賀町（第 2 図-B）

この地域では丘陵の南縁付近に位置しており, 第 四系のほぼ北縁を限っている(河田，1939). しかし 広域に分布する新旧の扇状地面を切る変位地形は認 められず，第四紀後期の活動は活発とは思われない.

（3）かつらぎ町周辺（第 2 図-B）

この地域では丘陵南縁に沿って位置しているが, 結晶片岩と和泉層群の接触関係はかなり複雑である (Miyata et al., 1974 ; 近畿西部 MTL グループ, 1977 ; 寒川・岡田，1977).ほぼ中央構造線に沿う 位置で, 北側の基盤岩 (多くは和泉層群で, 部分的に 三波川結晶片岩のこともある) と南側の菖蒲谷層が
逆断層関係(走向: $\mathrm{N} 70^{\circ} \mathrm{E} \sim 80^{\circ} \mathrm{E}$, 傾斜 : $40^{\circ} \sim 50^{\circ}$ $\mathrm{N}$ が多い) で接している.これに沿って直線状の 急斜面がみられるが，段丘面の変位は認められない。

（4）高野口町〜橋本市北方（第 2 図-B）

中央構造線の位置は Miyata et al. (1974), 近畿 西部 MTL グループ (1977) などの最近の研究によ って詳しく調べられている.これに沿って菖蒲谷層 と基盤岩（和泉層群または結晶片岩）との断層関係 が認められるが，これらの多くは変位地形として表 現されていない(寒川ほか，1977). 高野口町北方で, 段丘面の変位地形もわずかに認められている（寒川。 1976）が, 五条谷断層に比べて変位地形の鮮明さで はるかに劣っている.

\section{VI 考察}

1） 根来断層の断層運動速度と断層運動の性格 根来断層沿いの扇状地面は第 1 表のように区分さ れる. これらの扇状地面と堆積物は, 紀ノ川中流域 （寒川，1977）や，地形環境のよく似ている四国の 吉野川流域・石鎛断層崖北麓のもの（岡田，1968， 1970，1973 a,b)にほぼ対比することができる.

このうち, $\mathrm{tl}_{2}$ 面に対比される面の堆積物からは, 数多くの ${ }^{14} \mathrm{C}$ 年代試料が採集され，2.5 3× $10^{4} \mathrm{y}$. B.P. という形成年代が与光られている(岡田，1968， 1970, 1973 a, b).これより古い地形面については直 接的には絶対年代資料が得られていない。しかし最 近では, 関東や大阪地域での地形面は, それらを被 覆したり, 堆積物中に含まれる火山灰層や下位の地 層中からの Fission-Track 年代が多く求められてお り，形成年代がほぼ判明してきた（町田・鈴木, 1971 ; 石田, 1970 ほか). これらの值や, 古土堙の 発達状態・地形面の保存状態などを参考にして当域 の地形面の形成年代を次のように推定した。

$\mathrm{tl}_{1}$ 面を $5 \sim 6$ 万年前頃（武蔵野面にほぼ相当）, $\mathrm{tm}$ 面を $10 \pm 2$ 万年前頃（小原台面から下末吉面に ほぼ相当)，th 面を $20 \sim 30$ 万年前頃 (多摩面にほぼ 
第 1 表 調査地域の地形面と堆積物の特徵

\begin{tabular}{|c|c|c|c|c|}
\hline $\begin{array}{l}\text { 粉河町以西に拊 } \\
\text { る段丘面の分類 }\end{array}$ & 赤色風化殻 & 礫(和泉砂岩礫)の風化状態 & 地形面の保存状態 & \begin{tabular}{|l} 
粉河町以東に护 \\
る段丘面の分類 \\
(寒川, 1977) \\
\end{tabular} \\
\hline & $\begin{array}{l}\text { 最大 } 5 \sim 10 \mathrm{~m} \text { の厚さ } \\
\text { 色調 }(2.5 \mathrm{YR} \sim 10 \mathrm{R})\end{array}$ & ほとんどくさり礫 & $\begin{array}{l}\text { 背面（局所的に堆積原面を } \\
\text { 残す） }\end{array}$ & 五 条 面 \\
\hline $\begin{array}{l}\text { th 面 } \\
\text { (堆 積 物) }\end{array}$ & $\begin{array}{l}\text { 最大 } 1.5 \sim 2 \mathrm{~m} \text { の厚さ } \\
\text { 色調 }(2.5 \mathrm{YR} \sim 5 \mathrm{YR})\end{array}$ & くさり礫が多い & $\begin{array}{l}\text { 堆積原面が局所的に残って } \\
\text { いる }\end{array}$ & 山田 面 \\
\hline \multirow{2}{*}{$\begin{array}{c}\operatorname{tm} \text { 面 } \\
\text { (堆 積 物) }\end{array}$} & $\begin{array}{l}1 \mathrm{~m} \text { 前後の厚さ } \\
\text { 色調 }(5 \mathrm{YR} \sim 7.5 \mathrm{YR})\end{array}$ & 半分程度くさり礫がまじる & 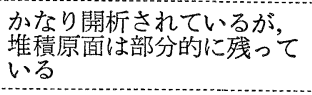 & 恋 野 面 \\
\hline & $\begin{array}{l}1 \mathrm{~m} \text { 以内の厚さ } \\
\text { 色調 }(7.5 \mathrm{YR})\end{array}$ & くさり礫を含む & $\begin{array}{l}\text { 開析されているが，堆積原 } \\
\text { 面は広く残っている }\end{array}$ & 山 蔭 面 \\
\hline $\begin{array}{l}\mathrm{tl}_{1} \text { 面 } \\
(\text { 堆 積 物) }\end{array}$ & な & $\begin{array}{l}\text { 全般に新鮮.かなり風化し } \\
\text { た礫も念竞が,くさり礫は } \\
\text { ほとんど含まない }\end{array}$ & $\begin{array}{l}\text { ほとんど開析を受けていな } \\
\text { い }\end{array}$ & 野 原 面 \\
\hline $\begin{array}{c}\mathrm{tl}_{2} \text { 面 } \\
(\text { 堆 積 物) }\end{array}$ & $"$ & $"$ & $"$ & 二 見 面 \\
\hline $\begin{array}{c}\mathrm{tl}_{3} \text { 面 } \\
\text { (堆 積 物) }\end{array}$ & $"$ & 新 鮮 & " & 今 井 面 \\
\hline
\end{tabular}

第 2 表 根来断層による段丘面・段丘崖の変位量とそれに基づく断層運動速度

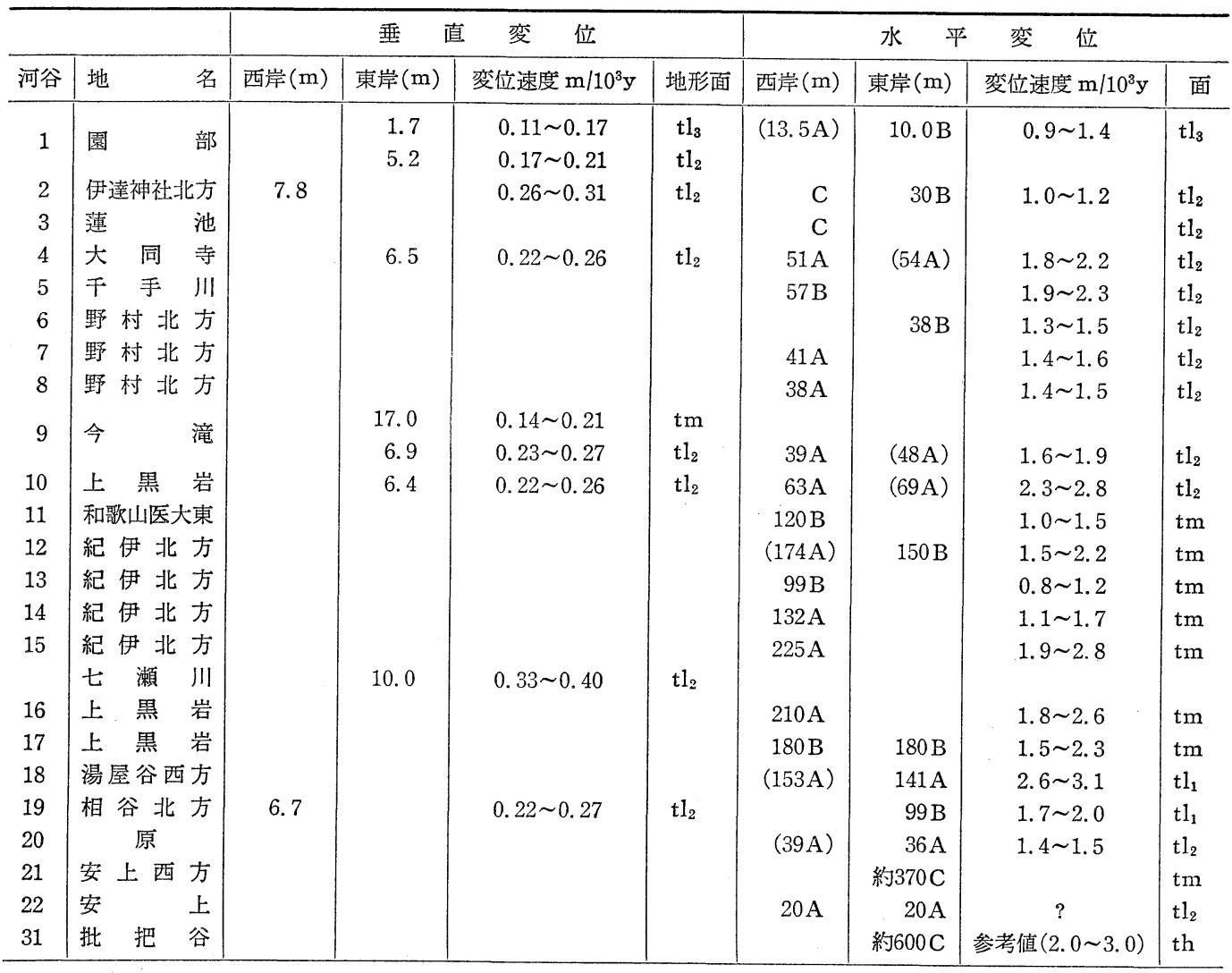


相当）とかなり幅をもたせて考えた. $\mathrm{tl}_{3}$ 面は $\mathrm{tl}_{2}$ 面 を切り込み，比高が現汇濫原とのほぼ中間に位置す るので 1 万〜 1 万 5 千年前頃に形成されたものと推 定した.

断層変位を受けた各地形面の形成年代を上述のよ うに定めて，それらの垂直・水平変位量をそれぞれ の形成年代で割算した断層変位速度を第 2 表に示し た.これによると，右ずれ速度は $\mathrm{tl}_{3}$ 面を刻む河谷 で，0.9 1. $4 \mathrm{~m} / 10^{3}$ 年， $\mathrm{tl}_{2}$ 面を刻む河谷で 1.0 $2.8 \mathrm{~m} / 10^{3}$ 年, $\mathrm{tl}_{1}$ 面を刻む河谷で $1.7 \sim 3.1 \mathrm{~m} / 10^{3}$ 年， $\mathrm{tm}$ 面を刻む河谷で $0.8 \sim 2.8 \mathrm{~m} / 10^{3}$ 年, 参考と して th 面を刻む河谷で $2.0 \sim 3.0 \mathrm{~m} / 10^{3}$ 年となり， 時代を異にする地形面を基準として求めた值がほぼ 同じになる．したがって第四紀後期には，ほぼ同じ 程度の水平変位速度で断層変位は累積してきたもの と考えられる.

垂直変位速度は， $\mathrm{tl}_{3}$ 面を切断するもので 0.11 $0.17 \mathrm{~m} / 10^{3}$ 年, $\mathrm{tl}_{2}$ 面を切断するもので $0.17 \sim 0.40$ $\mathrm{m} / 10^{3}$ 年, $\mathrm{tm}$ 面を切断するもので $0.14 \sim 0.21 \mathrm{~m} /$ $10^{3}$ 年と求められた．垂直変位は水平変位の約 10 分 の1の速度で進行していると考えられる。

根来断層に沿う各地点での水平・垂直変位速度を 第16図に示した.これによると，水平変位速度につ いては，根来断層内で大きな地域差はみられない。 垂直変位が，根来〜批把谷間で南側が相対的に上昇 しているが，これは和泉層群の分離丘陵が右ずれに
伴って移動して大きな河谷の出口を塞いだための見 掛け上の現象と推定される. 実際には，垂直変位は 北側の上昇が一般的な傾向であると考えられる.

2）活断層系の断層運動速度と断層活動の性格 活断層に沿って河谷が系統的に右ずれ屈曲してい るのは第 $V$ 章において記載した通りである. そのう ち，根来断層沿いでは段丘面を開析する河谷が多く 含まれている。 これらの段丘面は，形成年代の大略 が推定可能であるため, 断層変位量を測定すること によって断層変位速度の概略值を求めることができ た. その方法以外に，山地・丘陵地内の河谷につい て, 河谷の屈曲量 : Dと, 断層より上流の長さ : $\mathrm{L}$ の関係より間接的に断層変位量の推定を行なった.

従来よりDと Lに比例関係があることが述べられ ている(松田，1966，1975；安藤, 1972 ; 岡田, 1970, 1973 b) が，松田（1975)は D=aL の関係式が一般 に成り立つことを示し，日本のA級（変位速度によ る活断層の格付けは松田(1976)参照) 横ずれ活断層 では a の值が 0.1 1 であるとしている. さらに松 田(1975)は, 平均変位速度 : S と谷の屈曲率 : a の 間に, $\mathrm{S}\left(\mathrm{m} / 10^{3}\right.$ 年 $)=10 \mathrm{a}$ の関係がほぼ成り立つと している.

丘陵地・山地内の右ずれ屈曲を示す当域の河谷に つい，DとLの值(安藤(1972)の方法で求めた)を 第 3 表に示した。さらに，根来断層と五条谷断層, およびこの両断層を併合した 3 例について，それぞ

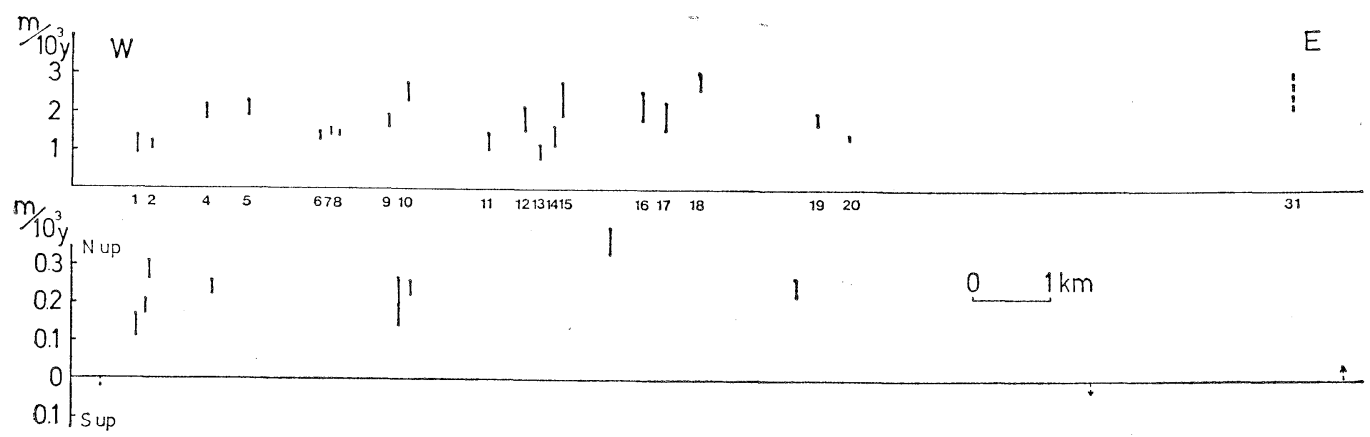

第16図根来断層による垂直・水平変位速度 数字は河谷番号を示す. 

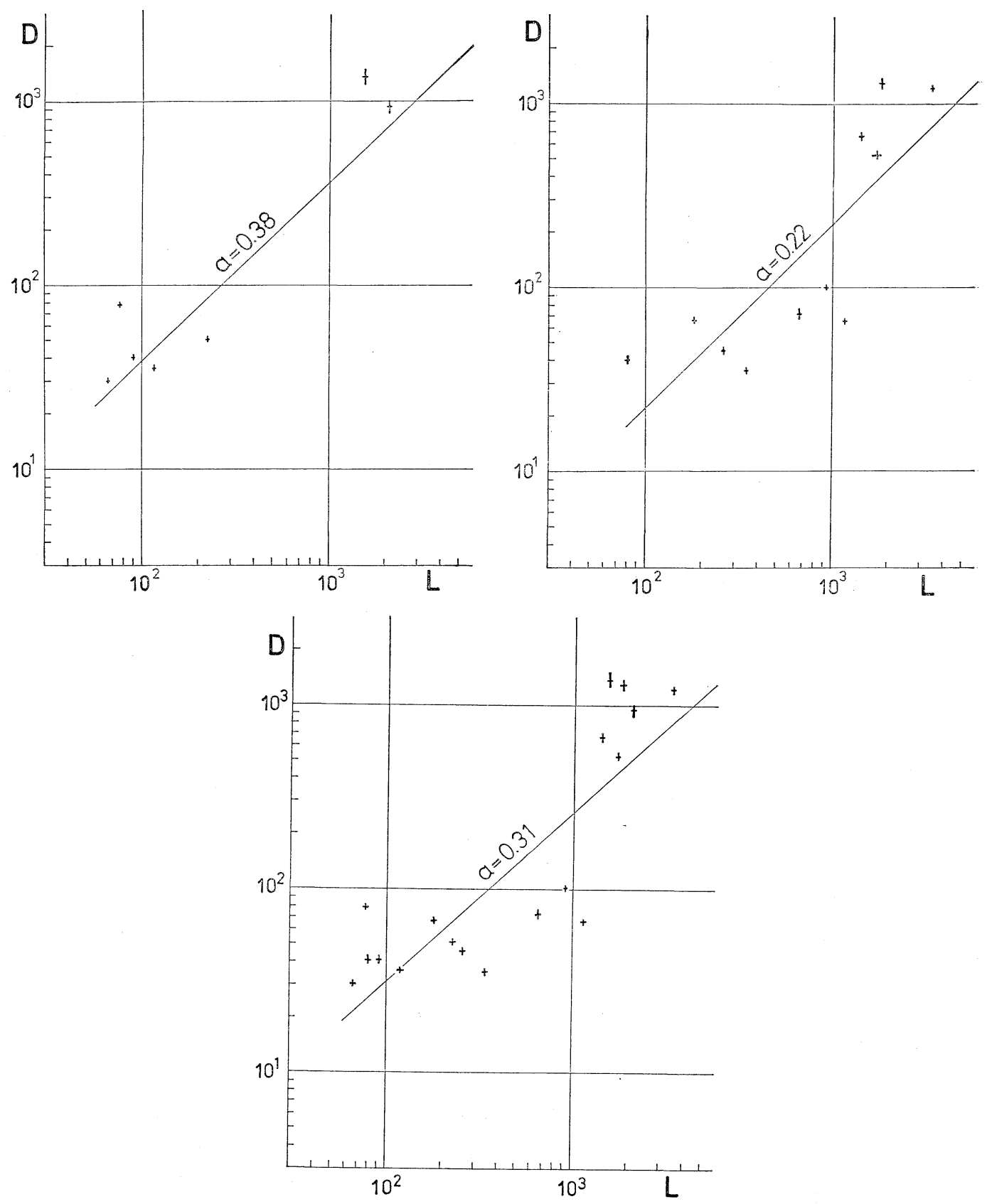

第17図 根来断層と五条谷断層に拈ける河谷の屈曲量 $(\mathrm{D})$ と断層より上流の長さ (L)の関係 左上:根来断層 右上:五条谷断層 下: 根来断層と五条谷断層.

れ相関係数を求め, 回帰直線を第17図に示した。 a される。

の值は, いずれも0.1以上であり，A級の活断層で さらに，Sの值が求められている根来断層につい あることを示しているが，根来断層の方が五条谷断て第18図にSとaの関係を図示し，松田(1975)が示 層より水平変位成分がややまさっていることが推定した他地域の主要活断層と活動度の比較を行なった。 
第3 表調查地域の活断層に沿う河谷の屈曲 量 $(\mathrm{D})$ と上流の長さ $(\mathrm{L})$ の関係

\begin{tabular}{|c|c|c|c|c|}
\hline & 河谷 & 地 & $\begin{array}{c}\text { 上流の長さ } \\
\quad(\mathrm{m})\end{array}$ & 屈曲量 (m) \\
\hline \multirow{3}{*}{ 根 } & 23 & 来寺 & 2,100 & $850 \sim 1,000$ \\
\hline & 24 & 根来クレー射撃場 & 75 & $75 \sim 80$ \\
\hline & 25 & 根来クレー射撃場 & 90 & 40 \\
\hline 来 & 26 & 根来クレー射撃場 & 400 & 55 \\
\hline 断 & 27 & 根来クレ一射撃場 & 65 & 30 \\
\hline 属 & 28 & 根来クレー射撃場 & 115 & 35 \\
\hline 厝 & 29 & 根来クレ一射撃場 & 225 & 50 \\
\hline & 30 & 根来クレー射擊場 & 1,560 & $1,200 \sim 1,480$ \\
\hline & 32 & 東山田東方 & 210 & 70 \\
\hline 监 & 33 & 東山田東方 & 240 & 200 \\
\hline 断 & 34 & 東 山田 菓 方 & 1,400 & 130 \\
\hline & 35 & 東山田東方 & 110 & 110 \\
\hline & 36 & 川 & 1,830 & $1,185 \sim 1,375$ \\
\hline & 37 & 上丹生谷北方 & 1,440 & 650 \\
\hline & 38 & 上丹生谷北方 & 80 & 40 \\
\hline 五 & 39 & $川$ & 1,725 & $485 \sim 545$ \\
\hline 条 & 40 & 葛 & $?$ & 20 \\
\hline & 41 & 葛 & 260 & 45 \\
\hline 谷 & 42 & 葛 & 925 & $95 \sim 100$ \\
\hline 断 & 43 & 葛 & 180 & 65 \\
\hline 層 & 44 & 那 & 3,420 & 1,175 \\
\hline & 48 & 大 & 340 & 35 \\
\hline & 49 & 大 & 655 & $65 \sim$ \\
\hline & 50 & 大 & 1,780 & 65 \\
\hline 中断 & 45 & 中 & 850 & 240 \\
\hline 尾層 & 46 & 中 & 560 & 175 \\
\hline $\begin{array}{l}\text { 大断 } \\
\text { 松層 }\end{array}$ & 47 & 大 & 460 & 550 \\
\hline
\end{tabular}

これによると，当地域の活断層系は四国の中央構造 線活断層系や阿寺断層よりやや不活発であるが，跡 津川断層や丹那断層よりは少し活動的であるとみな される.

3） 中央構造線活断層系の発生時期・活動 の転位時期

最近の研究（寒川ほか，1977；岡，1978）によれ ば，約 250 万年前から中央構造線の新しい活動が開 始して，和泉山脈はそれに伴って隆起し，それまで 外帯山地から大阪平野に通じていた古水系が和泉山 脈南縁で分断されたとみなされている.

このような断層活動によって狭義の中央構造線沿 いの断層系が第四紀前半まで活動的であったが，第

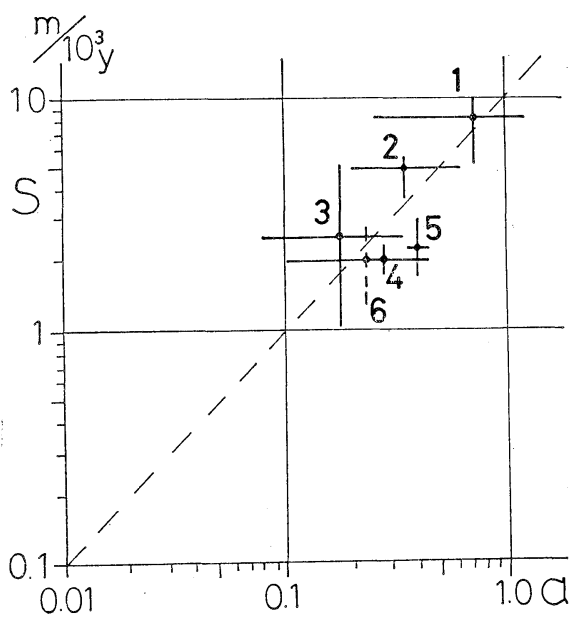

第18図根来断層 - 五条谷断層と他地域 の主要活断層の活動度の比較

1. 四国の中央構造線 2. 阿寺断層 3. 跡津川断層 4. 丹那断層 5. 根来断層 6 . 五条谷断層. 松田(1975)の資料に当域のものを付加.

四紀中期以降に和泉層群内を並走するさらに新しい 活断層系の活動がはるかに活発になっている.この 間に断層系の活動の様式が変化すると共に，断層系 の場所にも転位現象が生じている(寒川，1977)。そ して，第四紀後期の活断層系は右ずれ成分が卓越し ていることが明らかになったが，第四紀を通じて水 平・垂直変位の成分比がどのように変化してきたか については今のところ解明されていない，しかし， 根来断層や五条谷断層において最大 $1,500 \mathrm{~m}$ の河 谷の右ずれ屈曲が認められ，それらは $\mathrm{D}=\mathrm{aL}$ を大 略に执いて満たしていることや，最近数万年間の根 来断層の水平変位速度が $1 \sim 3 \mathrm{~m} / 10^{3}$ 年であること を考え合わせると，少なくとも50万年以前には右ず れの卓越傾向が発生していたと考えられる。

この時期は, 藤田 (1968，1976), 藤田・岸本 (1972), Huzita et al. (1973), 岡田, (1971, 1973 b), 藤田・ 太田(1977)が述べるように，第四紀中期以降に東西 圧縮力が強化されたことを反映していると思われる.

$$
\text { VII まとめ }
$$

和泉山脈南麓域の中央構造線活断層系の第四紀後 
期の断層活動について次のような知見が得られた.

1. 和泉山脈南麓域の活断層系（根来断層, 五条 谷断層など）において，右ずれを示す変位地形が連 続的に認められる.

2. 根来断層に沿って, 新旧の開析扇状地面が垂 直方向にも切断され，さらに，それを開析する河谷 が右ずれを示す系統的な屈曲をしている，これらの 扇状地面の形成年代を推定し, 段丘面 - 段丘崖 - 河 谷・尾根筋を基準として, 根来断層の水平 - 垂直変 位速度を求めた，それによると，水平変位速度は $0.9 \sim 3.1 \mathrm{~m} / 10^{3}$ 年, 垂直変位速度は $0.11 \sim 0.40 \mathrm{~m} /$ $10^{3}$ 年となり, 水平変位成分が約 1 桁卓越している ことが判明した.

3. 根来断層や五条谷断層について, $\mathrm{D}=\mathrm{aL}$ の関 係が成り立っており，根来断層が $\mathrm{a}=0.38$, 五条谷 断層が $\mathrm{a}=0.22$, 両者を合わせて計算すると $\mathrm{a}=$ 0.31 という值になる. これらのことより, 根来断 層・五条谷断層はともにA級の横ずれ活断層であり, 右ずれ変位が累積していることが判明した.

4. 和泉山脈南麓域の第四紀後期の断層変位速度 は，四国の中央構造線と比較すると，垂直方向でも 水平方向でもやや小さな值になっている.

5. 和泉山脈南麓域の中央構造線の断層運動は, 断層の性格や位置について第四紀の半ばに大きな変 化をとげている. すなわち，前期は紀ノ川断層角盆 地の形成に関した縦ずれ成分が強いと考えられる変 位で，それは狭義の中央構造線に沿って発生したも のである. 後期には，山脈の成長に強く関与し，右 ずれ成分の卓越する活動が継続している.これは, 和泉層群中に新たに発現した活断層系によるもので ある。

大阪市立大学の市川浩一郎・藤田和夫両先尘ならびに 下記の総合研究構成員の諸氏には現地て御教示や御討議 を受けた。ここに記して感謝の意を表する。なお，調查 費の一部には昭和 48 年度文部省科学研究費奖励研究 $\mathrm{A}$ 「中央構造線の第四紀断層運動諭 課題番号878077」打 よび50 52年度総合研究A「中央構造線の形成過程に関 する総合研究 課題番号034073」を使用した。

本研究は1976年日本地理学会春季学術大会に批いて発
表した。

（投稿 1977年10月 1 日）

（受理 1978年 2 月 4日）

文 献

安藤喜美子 (1972)：三浦半島・伊豆半島および兵庫 県山崎付近における断層の横ずれによる谷の変位 量について. 地理評，45，716 725.

石田志朗 (1970)：大阪層群一淡水・内海成互層の下 部更新統一. 第四紀研究，9，101 112.

市川浩一郎・宮田隆夫(1973)：中新世前の中央構造 線(とくに近畿地方)。杉山隆二編『中央構造線』 東海大学出版会, 87 95.

市川浩一郎・宮田隆夫・篠原正夫・河口雄三（1976 a)：根来断層について. MTL(中央構造線の形成 過程に関する総合研究一研究連絡誌一) , 1, 23 26.

市川浩一郎・宮田隆夫・政岡邦夫・篠原正夫（1976 b)：奈良県五条市北方の和泉層群中のカコウ岩塊。 MTL, 1, 27 30.

梅田甲子郎 (1973)：紀伊半島中部の中央構造線. 杉 山隆二編『中央構造線』東海大学出版会, 139 147.

岡 義記 (1978)：和泉山脈の形成と大阪層群。第四 紀研究，16，201 210.

岡田篤正 (1968)：阿波池田付近の中央構造線の新期 断層運動. 第四紀研究，7，15 26.

岡田篤正 (1970)：吉野川流域の中央構造線の断層变 位地形と断層運動速度. 地理諳，43，1 21.

岡田篤正 (1971)：動いている中央構造線.科学，41, $666 \sim 669$.

岡田篤正 (1972)：四国北西部における中央構造線の 第四紀断層運動. 愛知県立大学文学部論集 (一般 教育編)，23，68 94.

岡田篤正 (1973 a)：四国中央北縁部における中央構 造線の第四紀断層運動。地理評，46，295～322.

岡田篤正 $(1973 \mathrm{~b})$ ：中央構造線の第四紀断層運動に ついて．杉山隆二編『中央構造線』東海大学出版 会, 49 86.

岡田篤正 (1977)：中央構造線中央部における最新の 断層運動一沖積世の変位地形・変位量・地震との 関係について一. MTL，2，29〜44.

岡田篤正・寒川 旭 (1976)：和泉山地南縁における 中央構造線活断層系の活動様式と断層变位速度 （根来断層の新期断層運動について）．MTL， 1, $37 \sim 47$.

河田喜代助 (1939)：紀ノ川流域の “中央構造線”に 沿亏地質，矢部記念論文集，I，39～53. 
近畿西部 MTL グループ (1977)：和歌山県かつら ぎ町一高野口町地域の和泉層群の地質構造 (予報). MTL, 2, 71 76.

小林貞一 (1951)：『日本地方地質誌「総論一日本の 起源と佐川輪廻一」』朝倉書店, 353 ページ.

寒川 旭 (1976)：紀ノ川流域の地形形成と地殼変動. MTL, 1, 49 60.

寒川 旭(1977）：紀ノ川中流域の地形発達と地殼運 動. 地理評, 50, 578 595.

寒川 旭・岡田篤正(1977)：紀伊半島西部の中央構 造線の新期活動に関する断層露頭について.MTL， $2,51 \sim 60$.

寒川 旭・宮田隆夫・市川浩一郎(1977)：橋本市胡 麻生に打ける中央構造線の断層露 頭について. MTL, 2, 61 69.

寒川 旭・岡田篤正・岡 義記 (1977)：和泉山地の 形成と大阪層群・菖蒲谷層. 日本第四紀学会講演 要旨集，6，22.

志井田 功(1953）：竜門地方の新生代堆積物 “竜門 累層”について，奈良県総合文化調查報告書， 4 $\sim 18$.

志井田 功(1954)：吉野川流域の地質概要. 奈良県 文化調查報告書 吉野川流域, 1 13.

鈴鹿恒茂(1958)：『五条市史，地啠』497 516. 辻村太郎 (1924)：西南日本中央線の地形学的意義 $(1 \cdot 2 \cdot 3)$. 地質雑，31，110 119，155 166, $210 \sim 219$.

辻村太郎 (1932)：東北日本の断層盆地 (上・中・下). 地理評，8，641 658, 747 760, 977 992. 寺戸恒夫 (1967)：四国吉野川下流右岸の地形. 地理 科学, $8,28 \sim 38$.

藤田和夫 (1968)：六甲変動, その発生前後. 第四紀 研究, 7, 248 260.

藤田和夫 (1974)：第四紀地殼変動図「近畿」. 地質 調查所.

藤田和夫 (1976)：日本の山地形成論. 中尾佐助・加 藤泰安・梅棹忠夫編『山岳 森林 生態学』(今 西錦司博士古稀記念論文集 1), 中央公論社, 85 $\sim 140$.
藤田和夫・岸本兆方 (1972)：近畿のネオテクトニク スと地震活動. 科学, $42,422 \sim 430$.

藤田和夫・奥田 悟 (1973)：近畿・四国の中央構造 線のネオテクトニクス. 杉山隆二編『中央構造 線』東海大学出版会, 97 109.

藤田和夫・太田陽子（1977）：第四紀地殼変動。日 本第四紀学会編『日本の第四紀研究』東京大学出 版会, $127 \sim 152$.

町田 洋・鈴木正夫 (1971)：火山灰の絶対年代と第 四紀後期の編年——ィッション・トラック法に 上る試み——. 科学, $41,263 \sim 270$.

松田時彦 (1966)：跡津川断層の横ずれ変位. 地震研 彙報，44，1,179 1, 212.

松田時彦 (1973)：活断層としての中央構造線. 杉 山隆二編『中央構造線』東海大学出版会, 239 251.

松田時彦(1975)：活断層としての石廊崎断層系の評 価. 1974 年伊豆半島沖地震災害調査研 究報告, $121 \sim 125$.

松田時彦 (1976)：活断層と地震一七の地質学的研 究. 地質学論集, $12,15 \sim 32$.

Huzita, K. (1962): Tectonic development of the median zone (Setouchi) of South-west Japan since Miocene. Jour. Geosci. Osaka City Univ., 6, 103 144.

Huzita, K., Kishimoto, Y. and Shiono, K. (1973): Neotectonics and seismicity of Southwest Japan. Jour. Geosci. Osaka City Univ., 16, 93 124.

Kaneko, S. (1966) : Transcurrent displacement along the Median Tectonic Line, south-western Japan. New Zealand Jour. Geol. Geophys., 9, 45 59.

Kobayashi, T. (1961) : The Sakawa orogenic cycle and its bearing on the origin of Japanese Island. Jour. Fac. Sci. Imp. Univ., Tokyo, 2, 219 578.

Miyata, T., Maejima, W., Maeno, S., Ohira, Y. and Onishi, K. (1974) : En echelon faults along the Median Tectonic Line in Shobudani-Hirono District, Wakayama Prefecture, Southwest Japan. Jour. Geosci. Osaka City Univ., 17, 99 116. 


\title{
FAULT MORPHOLOGY AND QUATERNARY FAULTING ALONG THE MEDIAN TECTONIC LINE IN THE SOUTHERN PART OF THE IZUMI RANGE
}

\author{
Atsumasa OKADA* and Akira SANGAWA**
}

In the western part of the Kii Peninsula, the Median Tectonic Line separates the Izumi Range from the Kino-kawa lowland with a conspicuous topographical contrast, forming a great geological boundary between the Upper Cretaceous Izumi group of the Inner Zone and the Paleozoic crystalline schist of the Outer Zone, the latter of which is mostly overlain by the Plio-Pleistocene lacustrine sediments, the late Quaternary terrace gravels, and the Holocene alluvial deposits.

The writers investigated mainly fault features and related faulting along the southern foot of the Izumi Range. The results are briefly summarized as follows.

1) Many distinct evidences of the right-lateral movement are continuously discernible along the active fault system of the Median Tectonic Line in this area.

2) The Negoro fault, the principal fault in the western part of the area surveyed, vertically and horizontally interrupts the several steps of terrace surfaces (dissected fans) and the dissected valleys. Calculated from the known ages of the terrace surface, cliff, and dissected valley etc. across the active faults, which are roughly estimated by the correlation and the dated values such as carbon-14, fission track, and K-Ar methods in the neighboring areas, the mean rates of faulting are $0.9 \sim 3.1 \mathrm{~m} / 10^{3}$ years laterally, and $0.11 \sim 0.40 \mathrm{~m} /$ $10^{3}$ years in the vertically northward direation.

3) As the horizontal displacement (D) is in proportion to length $(\mathrm{L})$ of the river upstream from the fault with a certain coefficient of correlation (a), the relation is expressed as $\mathrm{D}=\mathrm{aL}$. Calculation gives the coefficient, $\mathrm{a}=0.38$ for the Negoro fault and $\mathrm{a}=0.22$ for the Gomyō-dani fault, the principal one in the eastern half of this area. They implicate that the both are among the most active transcurrent faults in the inland Japan, and that the displacements have been taken place with an almost uniform rate at least during the late Quaternary.

4) The mean slip rates of vertical and horizontal displacements in this area are slightly lower in comparison with those in Shikoku. This may be accounted for by the fact that this area is located at the eastern end of the active fault system of the Median Tectonic Line, and that the displacements are scattered among many other active faults in the Inner Zone of the Kinki district.

5) There are some differences in place and mode of displacement among the faults along the Median Tectonic Line int his area. Reverse faulting, which occurred in the first half

\footnotetext{
Geographical Review of Japan 51-5 385 405 1978 * Aichi Prefectural University.

** Graduate Student, Tohoku University. 
of the Quaternary along the great geological boundary, formed the general outline of the fault angle depression. On the contrary, right-lateral faulting began from the middle Quaternary as the new fracture within the uppermost Cretaceous Izumi group, and has continued to the present with a mountain-building movement. 